
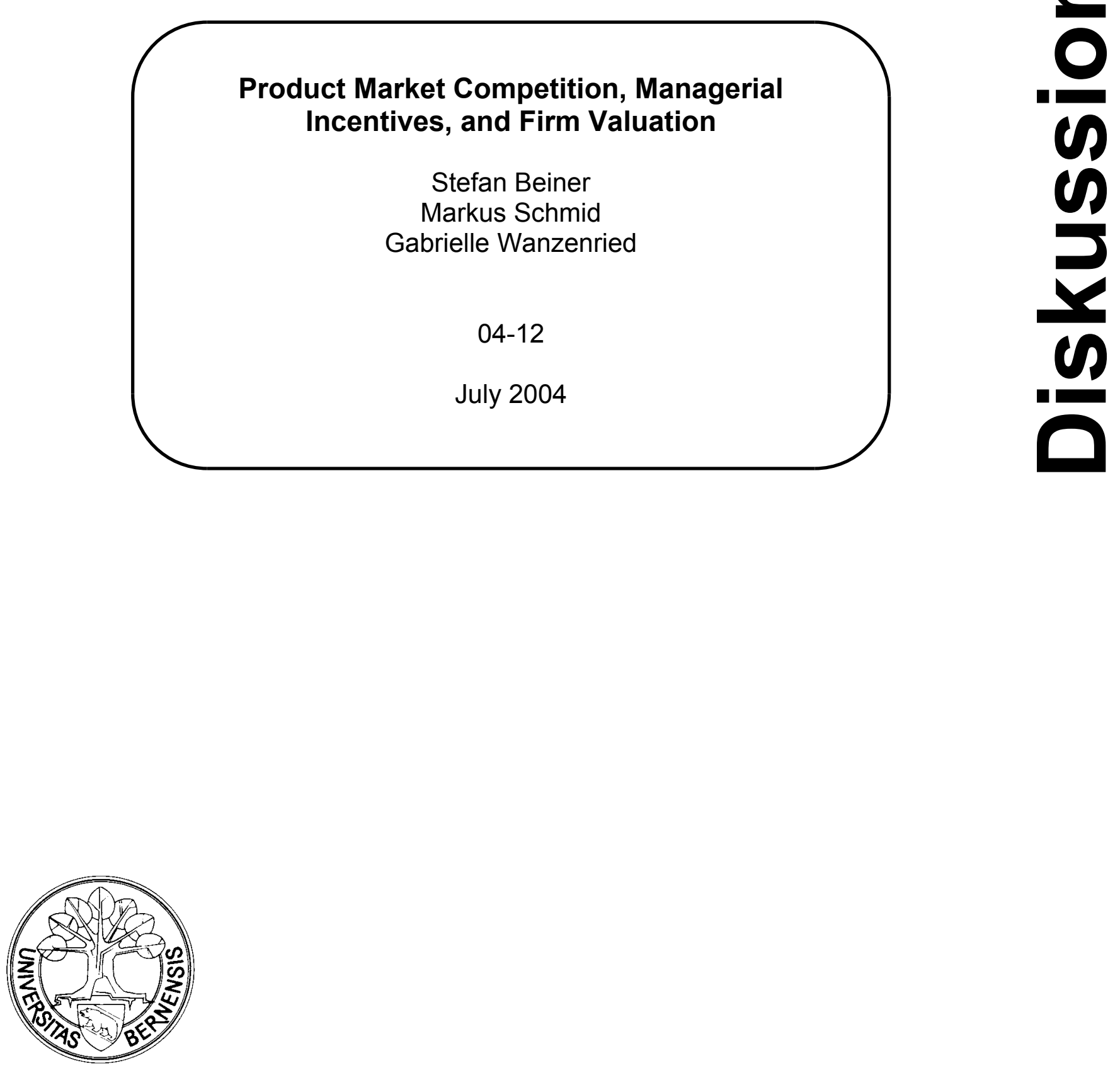

Universität Bern

Volkswirtschaftliches Institut

Gesellschaftstrasse 49

3012 Bern, Switzerland

Tel: 41 (0)31 6314506

Web: www.vwi.unibe.ch 


\title{
Product Market Competition, Managerial Incentives, and Firm Valuation
}

\author{
Stefan Beiner ${ }^{\mathrm{a}}$, Markus Schmid ${ }^{\mathrm{b}}$, and Gabrielle Wanzenried ${ }^{\mathrm{c}, *}$
}

This version: July 2004

\begin{abstract}
Our paper is a further contribution to the still very small empirical literature on the effects of competition on managerial incentive schemes. Based on a theoretical model that incorporates both strategic interaction between firms and a principal agent relationship, we investigate the relationships between product market competition, incentive schemes and firm valuation in a multivariate OLS framework. To take into account a possible endogeneity of the incentives provided to managers and Tobin's $Q$, our measure of firm value, we additionally employ a simultaneous equations framework. The sample comprises 156 Swiss firms for the year 2002, and the compensation data refer to the firms' top management and the board of directors in total. Our results suggest that more intensive product market competition is associated with stronger incentive schemes for managers and a lower firm value.
\end{abstract}

Key Words : $\quad$ Product Market Competition; Managerial Incentives; Firm Valuation; Simultaneous Equations System

JEL Classification: C31, J33, L1

\footnotetext{
a Stefan Beiner, Saïd Business School, University of Oxford, Park End Street, Oxford OX1 1HP UK, and Department of Finance, University of Basel, Holbeinstrasse 12, 4051 Basel, Switzerland, Mail: stefan.beiner@unibas.ch.

${ }^{\mathrm{b}}$ Markus Schmid, Department of Finance, University of Basel, Holbeinstrasse 12, 4051 Basel, Switzerland, Phone: +41-61-2673318, Mail: markus-max.schmid@unibas.ch.

c Gabrielle Wanzenried Haas School of Business, University of California Berkeley and Department of Economics, University of Bern, Mail: gabriell@haas.berkeley.edu.

* We thank Stefan Duffner, Ken Okamura and Edith Bernhard for support with data provision. Beiner acknowledges financial support from the Swiss National Science Foundation (SNF). All errors remain our responsibility.
} 


\section{Introduction}

What are the effects of product market competition on managerial incentives? Do managers work harder when the firm's environment is more competitive, i.e. do competition and incentive schemes substitute each other? And what are the impacts on firm value? While these and related questions are at the heart of an ongoing debate about corporate governance issues, the underlying mechanisms are only partly understood, and there is a serious lack of empirical evidence on these issues.

The effects of competition on incentive schemes and firm valuation are not only interesting from a purely academic point of view. These issues are also highly relevant for public policy makers. During the last decade, there has been an increasing influence of governments and non-governmental organizations on corporate governance rules. ${ }^{1}$ As Khemani and Leechor (2001) outline, much of the attention has focused on the firms and the regulations that protect shareholder rights and govern the conduct of management. However, the environment in which business is conducted, such as the degree of competition among firms, entry and exit rules, and the openness of the economy, requires close consideration. Competition is needed for a culture of good corporate governance to thrive. Competition policy helps to increase efficiency, reduce price distortions, lower the risk of poor investment decisions, promote greater accountability and transparency in business decisions, and lead to better corporate governance. Consequently, the design of effective corporate governance rules necessarily has to take into account the competitiveness of markets. While questions about the role of public policy are clearly beyond the scope of our paper, we should keep in mind that there may exist important interaction effects between competition and corporate governance rules.

The theoretical literature on the links between product market competition and managerial incentives can basically be divided into two main strands. A first strand analyzes the effects of product market competition on managerial incentives, but compensation contracts are not allowed to affect competition. While the earlier literature informally argues that competition reduces managerial slack (e.g., Machlup, 1967), Hart (1983) is the first to formalize this idea by modeling the effect of competition on the agency problems between a firm's owner and a manager. Subsequent research shows, however, that the relationship between competition and managers' effort level is ambiguous (e.g., Scharfstein, 1988; Hermalin, 1992; and Graziano

\footnotetext{
1 The OECD is about to revise its Principles of Corporate Governance that were adopted in 1999. In the USA, the Sarbanes-Oxley Act, which reinforces the firms' transparency requirements among others with respect to executive compensation, came into power in 2002. In Germany, the German Corporate Governance Code, a similar set of transparency rules that is however not compulsory, has recently been implemented by the German government. In Switzerland, the Swiss Code of Best Practice has become effective in 2002. The authorities of the European Union discuss the adoption of a corporate governance codex. See also Emons and Wanzenried (2003).
} 
and Parigi, 1998). ${ }^{2}$ While these studies rely on the information effect of competition, which means that competition induced by many firms in the market may give more precision to incentives based on relative performance evaluation, Schmidt (1997) uses the idea that more competition increases the probability of firms going bankrupt. He shows that the effects of competition on managers' effort level and the strength of their incentive schemes crucially depend on managers' outside options. In particular, an increase in the product market competition is more likely to result in stronger incentives in case managers have good outside options. Raith (2003) examines how the degree of competition among firms in an industry with free entry and exit affects the incentives for their managers. Such a setup with free entry and exit implies that changes in the nature of competition lead to changes in the equilibrium market structure. His results suggest an unambiguous positive relationship between competition and incentives. The second strand of the theoretical literature on competition and incentives is based on the idea that precommitment to managerial incentive contracts can alter the strategic competition between rivals. ${ }^{3}$ Aggarwal and Samwick (1999) extend the literature by considering compensation contracts based on relative performance evaluation. ${ }^{4}$

The empirical papers that relate product market competition to compensation are not very numerous and are mostly in line with Aggarwal and Samwick (1999), Kedia (2003) and Joh (1999). These studies explicitly take into account strategic interactions and the structure of product markets to explain managerial compensation contracts. In particular, they use these aspects to address the relative performance evaluation puzzle, which is the fact that empirical studies do not seem to find any role for relative performance evaluation in incentive contracts. Another recent paper by Funk and Wanzenried (2003) provides some evidence for Schmidts (1997) hypothesis that the relationship between competition and strength of incentives depends on the managers' outside options. Finally, Cuñat and Guadalupe (2004) study the impact of product market competition on the compensation packages in the US banking and financial industry.

\footnotetext{
2 Scharfstein (1988) reconsiders Hart's model while relaxing the assumption of infinitely risk-adverse managers. Hermalin (1992) considers additional effects of competition on the agency problem, all of which are of potentially ambiguous sign. Therefore, he concludes that theory cannot offer a definitive answer to the question of whether competition reduces managerial slack. Graziano and Parigi (1998) analyze the relationship between product market competition and managerial effort in a linear principal agent model. While increasing competition stemming from a lower degree of product market differentiation reduces the manager's optimal effort level and the optimal piece-rate, an increase in the number of firms has an ambiguous effect on effort and piece-rate.

3 See, e.g., Vickers (1985), Fershtman and Judd (1987), Sklivas (1987), and Fumas (1992).

4 They examine compensation contracts for managers in imperfectly competitive product markets and show that strategic interactions among firms can explain the lack of relative performance-based incentive schemes for which compensation decreases with rival firm performance. They find that firms in more competitive industries place more weight on rival firm performance relative to own firm performance. Their study is one of the very few papers that empirically test the relationship between incentives and competition.
} 
There is very few empirical evidence on the relation between product market competition and firm value. Griffith (2001) argues on page 1 that the direction of the effect that product market competition should have on firm value is ambiguous: „On the one hand increasing competition lowers firm's profits and thus reduces incentives to exert effort (the Schumpeterian effect), on the other hand it reduces agency costs (or increases the risk of bankruptcy) thus increasing incentives to exert effort." However, the empirical literature is mainly concerned with the effect of product market competition on productivity growth instead of firm value. For example, Nickel et al. (1997) find that product market competition has a positive impact on total factor productivity. ${ }^{5}$ Consistently, Januszewski et al. (2002) find for a sample of almost 500 German firms in the manufacturing industry that firms experience higher productivity growth when operating in markets with intense competition. Grosfeld and Tressel (2001) analyze the impact of competition and corporate governance on firm performance for firms listed on the Warsaw Stock exchange. They find that product market competition and good governance tend to reinforce each other. ${ }^{6}$ One exception is Habib and Ljungqvist (2004) investigating the effect of product market competition, as measured by a Herfindahl index based on four-digit SIC codes, on firm value. They provide evidence that firm value is positively related to product market competition.

The aim of our paper is to contribute to the still very small empirical literature on the relationship between product market competition and managerial incentives. Based on a theoretical model that incorporates both strategic interaction between firms and a principal agent relationship, we use a multivariate OLS framework to empirically investigate the relationships between product market competition, incentive schemes, and firm valuation for Swiss companies.

We consider a principal-agent model in a Cournot oligopoly setup. Such a setup not only takes into account the classical moral hazard problem within the firm, which is induced by the unobservability of the manager's effort, but it also incorporates strategic interaction between the firms. The model is structured as follows: At stage one, the firm owner hires a manager whose task is to reduce the firm's costs. At stage two, the manager decides on his unobservable effort level. At the last stage, finally, the firms compete with each other on output markets. The theoretical predictions of the model are threefold. First, the relationship between the strength of the incentive scheme and the intensity of competition depends on the

\footnotetext{
5 See, e.g., Nickell et al. (1997) for a summary of empirical evidence on the effect of product market competition on productivity performance.

6 See, e.g., Carlin and Horvath (2000) for a summary of empirical evidence on the impact of competition on firm performance in transition economies.
} 
absolute level of competition. For low levels of competition, more competition leads to weaker incentives. For higher levels of competition, however, a higher intensity of competition results in stronger incentives. Second, the relationship between the intensity of competition and the strength of the incentive schemes increases in the level of competition. Third, the effect of competition on firm value is negative, meaning that firms in more competitive environments realize lower profits.

Our data comprises information about firm characteristics and top management's and board of directors' compensation of 156 firms quoted at the Swiss Exchange (SWX) for the year 2002. In addition, we use three different variables for measuring the intensity of competition on product markets, namely one firm-specific and two industry-specific measures. The firmspecific measure is based on firms' rents from production and other business activities. The two industry-specific competition measures are a sales-based Herfindahl index and an indicator that measures the intensity of regulations for entering a new industry. We use a multivariate OLS regression analysis to investigate the relationship between product market competition, managerial incentives and firm value. Based on Agrawal and Knoeber (1996) and Beiner et al. (2004), we additionally apply a simultaneous equations framework in order to take into account a potential endogeneity problem.

The empirical results reveal that in general a more intense product market competition is associated with stronger incentive schemes for managers as measured by the fraction of sharebased to cash compensation. This result is consistent with the first hypothesis of our theoretical model and suggests that firms are operating in competitive environments on average. Moreover and consistent with our second hypothesis, we find the positive influence of competition on incentive schemes to be stronger for firms operating in a high competition environment. Finally and consistent with the third hypothesis of our theoretical model, we find a positive but not statistically significant effect on firm value for all three competition proxies indicating that a higher product market competition is associated with a lower firm value. Thus, the negative effect of lower economic rents seems to outweigh the positive effect of reducing managerial slack and increasing the managers' effort by providing additional monitoring and increasing the threat of liquidation.

The new aspects of our paper are the following ones: It is the first study that provides empirical evidence on the effects of competition on managerial incentives and firm valuation for Swiss companies. Furthermore, our empirical framework based on a simultaneous equations system suggests a way to deal with the potential endogeneity problem between 
competition, incentives and firm valuation. Finally, our theoretical principal-agent model explicitly takes into account the strategic interactions between firms without relying on the information effect of competition and the relative performance evaluation. This feature of the model allows us to formulate our hypothesis in terms of observable variables, which makes it particularly attractive for empirical tests.

The paper is structured as follows. The theoretical model and our main hypotheses are in section 2. Section 3 describes the data. The empirical analysis is in section 4 , and section 5 comprises some robustness tests. Section 6 concludes.

\section{Theoretical model and main hypotheses}

\subsection{The setup}

The purpose of our model is to investigate the effect of product market competition on the incentive schemes for managers and the value of the firm when there are strategic interactions between the market players. ${ }^{7}$ We consider a principal-agent model within a Cournot oligopoly setup, where the owner of the firm hires a manager to reduce marginal costs. In contrast to other work, our model neither relies on the information effect of competition, nor on relative performance evaluation, which both impose rather strong constraints in terms of observability of certain variables. The model has three stages. At stage one, the owner of firm $i$ hires a manager who has to reduce the costs of the firm. At stage two, the manager provides effort that affects the firm's marginal production cost. The manager's effort decision is unobservable to the owner, who can only observe the cost reduction. At stage three, the owner decides on the output level, profits are realized and the manager gets paid.

Each firm $i$ has constant marginal costs given by $c_{i}=\left(\bar{c}-e_{i}-u_{i}\right)$, where $\bar{c}$ is a constant, $e_{i}$ is the effort level exerted by the manager, and $u_{i}$ is a random term that is assumed to be normally distributed with zero mean, variance $\sigma^{2}$, and is independent of the other firms' shocks. The manager's effort level is not observable. The owner of the firm can only observe the realized costs $c_{i}$, which are also contractible. There are no fixed costs. The owner of the firm offers the manager a linear compensation scheme that is a function of the observed cost reduction, i.e.,

\footnotetext{
7 Our model is similar to Raith (2003), who considers the effects of competition on incentives within a circular city model with an endogenous determination of market structure.
} 


$$
w_{i}=\alpha_{i}+\beta_{i}\left(\bar{c}-c_{i}\right)
$$

The parameter $\alpha_{i}$ denotes the fixed part of the salary, and $\beta_{i}$ is the piece rate that ties the manager's wage to the performance of the company, and $\left(\bar{c}-c_{i}\right)$ is the observed cost reduction. Given that the cost reduction affects the profitability of the firm, we can interpret $\beta_{i}$ also as pay-for-performance sensitivity. ${ }^{8}$

The utility of the manager is given by $-\exp \left\{-r\left[w_{i}-g\left(e_{i}\right)\right]\right\}$, where $r$, with $r>0$, is the manager's degree of risk aversion, which we assume to be constant, and $g\left(e_{i}\right)=k e_{i}^{2} / 2$ is his disutility of exerting effort, with $k>1$. The expected value of the manager's wage is thus $\alpha_{i}+\beta_{i} e_{i}$ with variance of $\beta_{i}^{2} \sigma^{2}$. Given the normal distribution of $u_{i}$, the utility of the manager can be written as in (2), i.e.,

$$
U_{i}=\alpha_{i}+\beta_{i} e_{i}-\frac{r \beta_{i}^{2} \sigma^{2}}{2}-\frac{k e_{i}^{2}}{2}
$$

The manager accepts any contract $\left(\alpha_{i}, \beta_{i}\right)$ that gives him an expected utility of at least his reservation utility, which we normalize to zero.

The inverse demand function of firm $i$ is given by (3):

$$
p_{i}\left(q_{i}, q_{-i}\right)=a-b q_{i}-\sum_{j} d_{j} q_{j} \quad i, j=1, \ldots, N, i \neq j
$$

where $a$, with $a>0$ and $a>\bar{c}$, is the size of the market, $b$ is a positive constant, and $q_{i}$ is firm $i$ 's output. The variable $q_{j}$ is the output of firm $i$ 's rival $j$. The coefficient $d_{j}$, with $0<d_{j}<b$, captures the degree of product differentiation between the products on the market. The larger $d_{j}$, the closer substitutes the products are. The parameter $d_{j}$ is commonly used to measure the degree of competition in a market, where higher values imply a more intensive competition. ${ }^{9}$ To keep things simple, we set $b=1$ and $d_{i}=d_{j}=d, \forall i \neq j$. We further assume that there are only two firms in the market. We are looking for the subgame perfect equilibrium of the game. Therefore, we solve the model by backwards induction.

\footnotetext{
8 See, e.g., Jensen and Murphy (1990) and Murphy (1999).

9 See, e.g., Graziano and Parigi (1998).
} 


\subsection{The firm's output decision}

At $t=3$, the firms simultaneously choose their output levels. The profit of firm $i$ gross of managerial compensation is given by (4).

$$
\pi_{i}=\left(p-c_{i}\right) q_{i}=\left(a-q_{i}-d q_{j}-c_{i}\right) q_{i}, \quad i, j=1,2
$$

From maximizing (4) with respect to $q_{i}$ and solving for $q_{i}$ we get the firms' reaction function, i.e.,

$$
q_{i}\left(q_{j}\right)=\frac{a-c_{i}-d E\left(q_{j}\right)}{2}, \quad i, j=1,2
$$

If firm $i$ 's rival is expected to set a quantity of $E\left(q_{j}\right)$, the resulting profit of firm $i$ is as in (6).

$$
\pi_{i}\left(c_{i}, E\left(q_{j}\right)\right)=\left[\frac{\left(a-c_{i}-d E\left(q_{j}\right)\right)}{2}\right]^{2}, \quad i, j=1,2
$$

Simultaneously solving the system of two equations as given by (5) yields the equilibrium quantities of the third stage as a function of the firm's own marginal costs $c_{i}$ and the rival's expected costs $E\left(c_{j}\right)$, i.e.,

$$
q_{i}^{* * *}=\frac{2\left(a-c_{i}\right)-d\left(a-E\left(c_{j}\right)\right)}{\left(4-d^{2}\right)}, \quad i, j=1,2
$$

From substituting (7) into (3) we obtain the equilibrium price given by (8) and can compute the expected gross profits as given by (9):

$$
\begin{aligned}
& p_{i}^{* * *}=\frac{2\left(a+c_{i}\right)-d\left(a-E\left(c_{j}\right)\right)-d^{2} c_{i}}{\left(4-d^{2}\right)}, \quad i, j=1,2 \\
& \pi_{i}^{* * *}=\left[\frac{2\left(a-c_{i}\right)-d\left(a-E\left(c_{j}\right)\right)}{\left(4-d^{2}\right)}\right]^{2}, \quad i, j=1,2
\end{aligned}
$$

\subsection{The manager's effort decision}

At $t=2$, the manager of firm $i$ chooses his effort level by maximizing his utility given in (2): 


$$
\max _{e_{i}} U_{i}=\alpha_{i}+\beta_{i} e_{i}-\frac{1}{2} r \beta_{i}^{2} \sigma^{2}-\frac{k}{2} e_{i}^{2} \quad i, j=1,2
$$

Differentiating (10) with respect to $e_{i}$ yields the effort level as a function of the compensation parameter $\beta_{i}$, i.e.,

$$
e_{i}\left(\beta_{i}\right)=\frac{\beta_{i}}{k} \quad i, j=1,2
$$

The individual rationality constraint (IRC) of the manager $i$ is given by

$$
\alpha_{i}+\beta_{i} e_{i}-\frac{1}{2} r \beta_{i}^{2} \sigma^{2}-\frac{k}{2} e_{i}^{2} \geq 0 \quad i, j=1,2
$$

where the manager's outside utility is normalized to zero. Assuming competitive labor markets, the (IRC) is binding, which also means that (12) holds with equality. This allows us to calculate the fixed salary component $\alpha_{i}$ the manager has to be paid in order to have a reservation utility of zero.

$$
\alpha_{i}^{* *}\left(\beta_{i}\right)=-\frac{\beta_{i}^{2}\left(1-k r \sigma^{2}\right)}{2 k} \quad i, j=1,2
$$

The manager's wage as a function of $\beta_{i}$ is then given by

$$
w_{i}^{* *}\left(\beta_{i}\right)=-\frac{\beta_{i}^{2}\left(1-k r \sigma^{2}\right)}{2 k}+\beta_{i}\left(\bar{c}-c_{i}\right) \quad i, j=1,2
$$

\subsection{The optimal incentive scheme}

At the first stage of the game at $t=1$, the owner of the firm chooses the incentive scheme for the manager. He maximizes his expected profit net of manager's wage, which is given by (9) minus (14). Using $\left(\bar{c}-c_{i}\right)=e_{i}+u_{i}, e_{i}\left(\beta_{i}\right)=\beta_{i} / k$, and $E\left(u_{i}\right)=0$, the net expected profit is given by (15).

$$
\pi_{n e t, i}\left(\beta_{i}\right)=\frac{\left[2\left(a-\left(\bar{c}-\frac{\beta_{i}}{k}\right)\right)+d\left(E\left(c_{j}\right)-a\right)\right]^{2}}{\left(4-d^{2}\right)^{2}}+\frac{\beta_{i}^{2}\left(1-k r \sigma^{2}\right)}{2 k}-\beta_{i} \frac{\beta_{i}}{k}, \quad i, j=1,2
$$

Differentiating (15) with respect to $\beta_{i}$ and solving for $\beta_{i}$ leads to 


$$
\beta_{\mathrm{i}}=\frac{4 k\left(2(a-\bar{c})+d\left(E\left(c_{j}\right)-a\right)\right)}{\left(k+k^{2} r \sigma^{2}\right)\left(4-d^{2}\right)^{2}-8}, \quad i, j=1,2
$$

In a symmetric equilibrium, all firms choose the same piece rate $\beta$, and each manager chooses the same effort level $e$. Accordingly, $E\left(c_{j}\right)=\bar{c}-e=\bar{c}-\beta / k$. Substituting this expression into (16) and solving for $\beta$ leads to (17), the optimal incentive parameter.

$$
\beta^{*}=\frac{4 k(a-\bar{c})}{\left(k+r \sigma^{2} k^{2}\right)\left(-d^{3}-2 d^{2}+4 d+8\right)-4}
$$

To find the equilibrium quantity and profit net of managerial compensation, we plug (17) into the corresponding second-stage equilibrium values, which yields the following results:

$$
\begin{aligned}
& q^{*}=\frac{\left(k+r \sigma^{2} k^{2}\right)\left(4-d^{2}\right)(a-\bar{c})}{\left(k+r \sigma^{2} k^{2}\right)\left(-d^{3}-2 d^{2}+4 d+8\right)-4} \\
& \pi_{n e t}^{*}=\frac{\left(1+r \sigma^{2} k\right)(a-\bar{c})^{2} k\left[\left(k^{2} r \sigma^{2}+k\right)\left(d^{2}-4\right)^{2}-8\right]}{\left[\left(k^{2} r \sigma^{2}+k\right)\left(d^{3}+2 d^{2}-4 d-8\right)+4\right]^{2}}
\end{aligned}
$$

\subsection{The effects of competition on the strength of incentive schemes and firm value}

How does competition affect the optimal pay-for-performance sensitivity $\beta^{*}$ and firm value? Following Graziano and Parigi (1998), we use the degree of product differentiation $d$ as a proxy for the intensity of competition. The larger $d$, the closer substitutes the products are, and the higher the intensity of competition. As to firm value, we look at the profit net of manager's compensation.

From differentiating the optimal pay-for-performance sensitivity as given by (17) with respect to competition measure $d$ we obtain

$$
\frac{\partial \beta^{*}}{\partial d}=\frac{4 k^{2}(a-\bar{c})(d+2)(3 d-2)\left(k r \sigma^{2}+1\right)}{\left[\left(k^{2} r \sigma^{2}+k\right)\left(d^{3}+2 d^{2}-4 d-8\right)+4\right]^{2}}
$$

To obtain the sign of this expression, we only need to look at the numerator since the denominator is always positive. Given that $a>\bar{c}$ by assumption, this expression is positive 
iff $d>2 / 3$. It follows that the owner of the firm more closely ties the manager's wage to the performance of the company once the intensity of product market competition has reached a certain level. This leads us to our first hypothesis.

Hypothesis 1: A higher intensity of product market competition, as measured by the degree of product differentiation d, leads to stronger incentive schemes for the manager in case the intensity of product market competition has reached a certain level, i.e., $\frac{\partial \beta^{*}}{\partial d}>0$ for $d>2 / 3$.

Obviously, there are different effects at work. First, there is a business stealing effect: a higher value of $d$ implies a more elastic demand, which makes it easier for a firm with a cost advantage to take away business from its rival. Accordingly, for a given quantity of its rival, a more intensive competition increases a firm's marginal benefit of reducing its costs. Given this first effect, the firm wants to give stronger incentives to its manager with increasing competition, leading to lower marginal costs. However, there is a second effect at work that can be denoted as a scale effect: a higher value of $d$ also leads to a fall in firm $i$ 's output. ${ }^{10}$ This decreases the firm's gain from reducing its costs and leads the firm to give weaker incentives to the manager when competition is increasing. While the second effect, the scale effect, is dominating for lower values of $d$, the formerly described business stealing effect starts to dominate once the degree of competition has reached a certain level, i.e., for values of $d>2 / 3$. Accordingly, for lower values of $d$, the incentive parameter $\beta$ is decreasing when the intensity of competition is increasing; for higher values of $d$, in contrast, the incentive parameter $\beta$ is increasing in the intensity of competition parameter. In other words: For values of $d>2 / 3$, firms provide stronger managerial incentives because greater competition increases the value of making good decisions (i.e., the business stealing effect increases).

To understand the underlying mechanisms from a formal point of view, we can look at firm $i$ 's marginal gain of reducing its costs, i.e., let us differentiate (9) with respect to $c_{i}$ :

$$
\frac{\partial \pi_{i}^{* * *}}{\partial c_{i}}=-\frac{4\left[2\left(a-c_{i}\right)-d\left(a-E\left(c_{j}\right)\right)\right]}{(d-2)^{2}(d+2)^{2}}
$$

In a symmetric equilibrium, expression (21) is clearly negative. This reflects the fact that the firm can increase its profit by lowering its costs. To see how the marginal profit of a cost reduction moves with the intensity of competition, which is really our main interest, we go

\footnotetext{
${ }^{10}$ This can best be seen by differentiating the equilibrium output level as given by (18) with respect to $d$, which is clearly negative. From an economic point of view, the willingness to pay for the product of firm $i$ decreases with a higher value of $d$, i.e., the closer substitutes the products are. As we can see from firm $i$ 's reaction function as given by (5), a higher value of $d$ leads to a lower output for firm $i$. This is to compensate the fall in profits due to the lower price.
} 
one step further and differentiate (21) with respect to the degree of product differentiation $d$ that yields (22):

$$
\frac{\partial\left[\frac{\partial \pi_{i}^{* * *}}{\partial c_{i}}\right]}{\partial d}=\frac{4\left[\left(3 d^{2}+4\right)\left(E\left(c_{j}\right)-a\right)+8 d\left(a-c_{i}\right)\right]}{(d-2)^{3}(d+2)^{3}}
$$

In a symmetric equilibrium expression (22) is positive for $d<2 / 3$, whereas (22) is negative for $d>2 / 3$. A positive sign of (22) means that the marginal profit of a cost reduction, which is a negative value, becomes less negative and thus smaller in absolute terms when $d$ is increasing. This reflects the fact that the scale effect is dominating and the firm lowers the incentive parameter $\beta$ when the intensity of product market competition is increasing. The negative sign of expression (22) for $d>2 / 3$, in contrast, mirrors the dominance of the business stealing effect: The marginal profit of a cost reduction becomes larger in absolute terms with a higher intensity of competition $d$, and this induces the firm to give stronger incentives to its manager. To see how the relationship between the incentive parameter $\beta$ and $d$ changes with different levels of competition, we go another step further and differentiate (20) with respect to $d$, i.e.,

$$
\frac{\partial\left(\partial \beta^{*} / \partial d\right)}{\partial d}=\frac{16 k^{2}(a-\bar{c})\left(1+k r \sigma^{2}\right)\left[\left(k^{2} r \sigma^{2}+k\right)\left(16+8 d^{3}+3 d^{4}\right)-4-6 d\right]}{\left[\left(k^{2} r \sigma^{2}+k\right)\left(-d^{3}-2 d^{2}+4 d+8\right)-4\right]^{3}}
$$

Expression (23) is positive, which also means that the marginal effect of competition on the incentive parameter becomes stronger with increasing competition. To see this, we only need to look at the square brackets in the numerator since all other expressions are positive. Within the square bracket, the product is always equal to or bigger than 16 , since $k$ is equal to or bigger than one and $r$ is positive. Therefore, the considered expression in the square brackets is positive for all values of $d$ (to remember: $0 \leq d \leq 1$ ). This expression becomes even larger with higher values of $k$. These considerations lead us to our second hypothesis:

Hypothesis 2: The marginal effect of competition on the incentive parameter $\beta$ increases with the intensity of product market competition, as measured by the degree of product differentiation $d$, i.e., $\frac{\partial\left(\partial \beta^{*} / \partial d\right)}{\partial d}>0$ for $\forall d$.

As to the effect of competition on firm value, we differentiate the net profit as given by (19) with respect to $d$, which yields (24). 


$$
\frac{\partial \pi_{n e t}^{*}}{\partial d}=\frac{2\left(1+r \sigma^{2} k\right)^{2} k^{2}(a-\bar{c})^{2}(d+2)^{2}\left[\left(k^{2} r \sigma^{2}+k\right)\left(d^{4}-4 d^{3}+16 d-16\right)-8 d+8\right]}{\left[\left(k^{2} r \sigma^{2}+k\right)\left(-d^{3}-2 d^{2}+4 d+8\right)-4\right]^{3}}
$$

Expression (24) is clearly negative: From before, we know that the denominator is always positive. As to the numerator, we only need to look at the square brackets since all other expressions are positive. Within the square bracket, the product is always equal to or bigger than -16 , since $k$ is equal to or bigger than one and $r$ is positive. Since $k>1$ and $-8 d+8$ is equal or smaller than 8 for all values of $d$, the expression in the square bracket is always negative. These considerations lead us to our third hypothesis.

Hypothesis 3: A higher intensity of product market competition, as measured by the degree of product differentiation d, leads to a lower net profit, i.e. $\frac{\partial \pi_{n e t}^{*}}{\partial d}<0$ for $\forall d$.

The explanation of this result is straightforward and stands in line with standard oligopoly models. The closer we move to perfect competition in terms of having more homogenous products, c.p., the lower the profits of the firms are.

The hypotheses derived from our theoretical model are subject of our empirical tests in sections 4 and 5 .

\section{Data and sample}

\subsection{Definition of variables}

\subsubsection{Product market competition}

In this section we provide a detailed description of the variables we use in our empirical analysis. Similar to Nickell (1996), Nickell et al. (1997) and Grosfeld and Tressel (2001), our standard measure of product market competition is a firm's rents from production and other business activities, Rents, which can be interpreted as an ex-post measure of market power. The motivation for using this measure is that firms operating in less competitive markets should be able to sell their products well above marginal costs and, therefore, earn higher rents after covering their expenses. We define Rents as profits before interest payments, tax, and depreciation $(E B I T D A)$ minus the costs of capital $(c c)$ multiplied by total assets $(T A)$ and standardized by the company's sales $(S A)$ :

$$
\text { Rents }=(E B I T D A-c c \cdot T A) / S A
$$


The costs of capital $(c c)$ are defined as follows:

$$
c c=r_{f}+\delta+\lambda \cdot \beta\left(r_{m}-r_{f}\right)
$$

where $r_{f}$ is the risk free rate, $\delta$ is the rate of depreciation, $\lambda$ is equal to the equity ratio of the firm, $\beta$ is the estimated market beta of the firm's stock, and $r_{m}$ is the return to a broad market index. The risk free rate is calculated as the average one month Swiss Interbank Rate over 60 monthly values from January 1997 to December 2001 and amounts to 1.92\%. Following Nickell (1996), the depreciation rate is assumed to be constant at 4 percent. ${ }^{11}$ The equity ratio, $\lambda$, is calculated as 1 minus the ratio of total (non-equity) liabilities to total assets. ${ }^{12}$ The market beta, $\beta$, is estimated by regressing the firm's monthly stock returns over the past five years on the respective returns of the market as proxied by the Swiss Performance Index (SPI). ${ }^{13}$ The risk premium is equal to the average return of the Pictet-Rätzer Index, a broad Swiss stock market index, less the average short-term interest rate (the one month Swiss Interbank Rate).

The main drawback of this type of measure of ex-post monopoly power is that it is clearly strongly correlated not only with market power but also with profitability, whatever the precise definition chosen (see also Nickell, 1996). Since we analyze the impact of product market competition on firm valuation and firm value is expected to be positively correlated with profitability, we may obtain a positive bias in our results. In fact, as our empirical results in Section 4 reveal, Rents affects firm value positively. To mitigate this potential bias, we control for the influence of profitability on Tobin's $Q$ by including an alternative measure, the return on assets, into our regression analysis.

In addition to the firm-specific competition indicator Rents, we employ two alternative industry-level measures of product market competition that are presumably not afflicted with this problem. Specifically, we use a sales-based Herfindahl index, Herf, and an indicator measuring the level of regulation for new industry entrants, $R e g$, as additional proxy variables for competition. Herf is calculated as follows:

\footnotetext{
${ }^{11}$ Alternatively, to test the robustness of our results to this assumption, we apply a second measure of rents based on a rate of depreciation of 8 percent, labeled as Rents 8 . The results change only immaterially (see Tables 8 and 9 in the robustness section).

12 Following Nickell (1996), we also apply an alternative measure of rents, RentsL1, where $\lambda$ is set equal to one. The results remain basically unchanged as Tables 8 and 9 in the robustness section reveal.

${ }^{13}$ For firms with more than one share category all variables related to stock return data are weighted based on nominal values. Firms with return data not available for the full period of 60 months are not excluded from our sample if return data could be obtained for at least 9 months.
} 


$$
H e r f=\sum_{i=1}^{N_{j}}\left(S A_{i j} / \sum_{i=1}^{N_{j}} S A_{i j}\right)^{2}
$$

where $S A_{i j}$ is the sales attributable to firm $i$ in industry group $j$, where industry groups are based on the classification of the Swiss Exchange (SWX). Each industry group comprises all quoted Swiss firms and not only the firms in our sample. As argued by Aggarwal and Samwick (1999), the Herfindahl index can be used as a proxy for product substitutability. Of course, there are also some problems associated with the use of Herf as a measure of market power. First, Herf does not take into account foreign competitors, a problem, which is likely to be especially severe in a small open economy as Switzerland. Second, our classification of industry groups is arbitrary and may not represent anything like the relevant product market for the firms included in the respective industries. ${ }^{14}$ Third, actual as well as potential competition influences the market power of firms within an industry and Herf does clearly not take into account the latter. However, Rents is supposed to be much less afflicted with these problems.

Our third competition proxy, Reg, measures the intensity of legal regulations for firms entering a new industry. This indicator is unique in the sense that is only available for Switzerland in this form. It goes back to a study that was commissioned by the Swiss government and is described in detail in Ledergerber et al. (1998). The purpose of the study was to build a simple indicator that measures the intensity of regulations by law area and by industry in Switzerland. The industry classification includes 32 industrial sectors and is based on the NOGA Industry Classification System. ${ }^{15}$ Without going too much into details, the construction of the indicator can be described as follows: In a first step, the relevant regulations imposed by federal law were classified into the five categories Information Rules, Qualitative Standards, Quantitative Standards, Permits, and Implementation by Cantons. This categorization goes back to Ogus (1994) and reflects the strength of regulations, in ascending order, and the implied costs for firms. The category Information Rules is the weakest form of interventions, whereas Permits represents the strongest regulation category. ${ }^{16}$ In a second step, the number of regulations by law area and by regulation category was derived. In addition, the industries affected by each regulation were identified. Finally, the indicator was built by first allocating specific weights to the number of regulations by categories, where

\footnotetext{
${ }^{14}$ To investigate this issue, we use an additional variation of Herf, which is based on an alternative industry definition, in the robustness section. In fact, we find some of the results to depend on the precise definition of Herf.

${ }^{15}$ NOGA stands for Nomenclature Générale des Activités Economiques.

${ }^{16}$ The category Implementations by Cantons was introduced to fit the specific characteristics of the Swiss system. It is parallel to the other categories and does not represent the strongest form of regulation.
} 
stronger regulations got larger weights, and then by building the sum of these weighted numbers. The higher the value of the indicator, the stronger is the impact of regulations for firms.

The regulation indicator Reg that we use in our study is a variation of the general indicator as described above. It is based on a smaller set of regulations that are specifically relevant for market entry. The weakest forms of interventions are categorized under Market Regulations, which include activities related to certifications, registrations or type tests of new products. The second category refers to Permits the firms have to apply for by the governmental authorities. The final category is denoted by Professional Licences, which are a recognized certification of professional capabilities. The higher the value of the indicator Reg, the stronger is the impact of the regulations for firms entering a new market.

Given that these regulations are barriers to entry, fewer firms are expected to enter in highly regulated industries. Therefore, we interpret a high value of Reg as a low intensity of product market competition. Note that we divided the original values as reported in the study by Ledergerber et al. (1998) by 1000. Also, the information refers to the time period before 1998 . We are aware of the fact that this indicator is not perfect, and it is vulnerable to all sorts of criticism. The weighting procedure, for instance, is not based on some objective criteria and is therefore rather arbitrary. Furthermore, the analysis is limited to federal law only, and the considered regulations mainly refer to small and medium companies. Nevertheless, this regulation indicator is still useful in the sense that it gives us some indication about the costs associated with entering a new industry or market, and this type of information is elsewhere hardly available.

Since all three proxy variables for product market competition measure different aspects of competition and, hence, are afflicted with other problems, it makes perfectly sense to include all three variables simultaneously into the empirical investigations. To cope with a potential endogeneity problem related to our competition measures, we use lagged values for Rents, Herf, and Reg. That is, in contrast to the other variables, which in general refer to the reporting period from January 2002 to December 2002, our competition proxies are based on 2001 data. $^{17}$

\footnotetext{
${ }^{17}$ The results obtained by using 2002 data for the competition proxies are reported in Tables 8 and 9 in the robustness section.
} 


\subsubsection{Measuring incentives for managers}

To measure the incentive schemes provided to managers, we use the percentage value of shares alloted in 2002 to the firm's officers and directors in total relative to cash compensation paid during the same year, Sratio. Besides the fraction of share-based to cash compensation to the firm's officers and directors, this paper considers four additional corporate governance mechanisms, which are assumed to provide incentives to managers and therefore alleviate the agency problems between managers and shareholders (see Beiner et al., 2004). Stocksod is the sum of all shares owned by officers and executive as well as nonexecutive members of the board divided by the total number of shares outstanding. ${ }^{18}$ Blocko denotes the percentage of cumulated voting rights exercised by large outside investors with voting rights exceeding $5 \%$. Outsider refers to outside membership on the board, measured by the percentage of board seats held by directors without any executive function. Leverage denotes firm leverage and is calculated as the ratio of total (non-equity) liabilities to total assets.

Besides these corporate governance mechanisms, we employ eight different control variables in this paper. Firm size is measured by the natural logarithm of total assets and is labeled Lnassets. As a measure of profitability, we include the return on assets, $R O A$, which is calculated as operating profit in 2002 divided by the average of the 2002 starting and ending value of total assets. Pgrowth is the average annual sales growth over the past three years (2000-2002). As it is standard in the literature on the relationship between pay and performance, we use the change in shareholder value, CSV , as a measure of firm performance in our investigations related to Sratio. Following Jensen and Murphy (1990) and Funk and Wanzenried (2003), we define $C S V$ as the return on equity multiplied by the market value of equity in the previous period. $S t d v$ is the standard deviation of 60 monthly returns of a firm's stock. Beta is the market beta estimated by regressing the firm's monthly stock returns over the past five years on the respective returns of the market as proxied by the Swiss Performance Index (SPI). CEOP is a dummy variable which is equal to one if the chief executive officer (CEO) is also president of the board of directors and zero otherwise. To control for industry effects, we include 9 dummy variables, labeled Industry, which are equal to one if the firm belongs to a particular economic sector based on the classification of the Swiss Exchange (SWX) and zero otherwise.

\footnotetext{
${ }^{18}$ Weighting has to be based on nominal values because market values are not available for all share categories of the firms in our sample. However, Schmid (2004) shows that for the 116 firms of his total sample of 145 Swiss firms for which he has market values for all existing share categories, the values of Stocksod are very close to those obtained by using nominal values to weigh the ownership of different share categories.
} 
Finally, our measure of firm valuation is Tobin's $Q$, alternatively simply labeled as $Q$. As suggested by Chung and Pruitt (1994), Perfect and Wiles (1994), Agrawal and Knoeber (1996), Kang and Stulz (1996), and Loderer and Peyer (2002), among others, Tobin's $Q$ is estimated as the ratio of the market value of equity plus the book value of debt to the book value of total assets. To avoid that fluctuations in the market value of firms' equity influence our results, we follow Beiner et al. (2004) and Schmid (2004) and compute the market value of equity as the mean of daily observations during $2002 .{ }^{19}$ Definitions of all variables employed in this study are also provided in Table 1.

[Insert Table 1 about here]

\subsection{Sample description}

As a starting point we target all 275 firms quoted at the Swiss Exchange (SWX) by the end of 2002. The exclusion of investment companies leaves us with a sample of 235 firms. Compensation data (Sratio, Stocksod) is available for 171 firms. Another 13 firms must be dropped because no data on Rents, our standard measure of product market competition, is available. Finally, the exclusion of two obvious outliers concerning their value of ROA and Rents leaves us with a sample of 156 firms for our cross-sectional regression analysis.

Data has been collected from different sources and generally refers to the reporting period from January 2002 to December 2002. The necessary data to compute Rents, Herf, Q, Leverage, Lnassets, ROA, Pgrowth, CSV, Stdv, and Beta were obtained from Datastream and Worldscope. Data for the variables Blocko, Bsize, Outsider, and CEOP stems from the website of "Finanz \& Wirtschaft"20 and the "Swiss Stock Guide 2002/2003". However, for most variables data was not available for all firms in our sample. Missing values were obtained from the companies' annual reports. Sratio and Stockod have been directly collected from the 2002 annual reports of the companies covered in this study. Reg is taken from the report "Regelungsdichte nach Branchen" by Ledergerber et al. (1998). Finally, the variable Industry is based on the classification of the Swiss Exchange (SWX) and stems from the SWX website. ${ }^{21}$

\footnotetext{
${ }^{19}$ For some firms daily stock price data is not available for all share categories on Datastream, and we replace them by the mean of the 2001 and 2002 year end values of total market capitalization obtained from Worldscope.

${ }^{20}$ The website of "Finanz und Wirtschaft", Switzerland's major financial newspaper, is: www.finanzinfo.ch.

${ }^{21}$ The website of the Swiss Exchange is: www.swx.ch.
} 


\subsection{Descriptive statistics}

Table 2 shows descriptive statistics of all variables included in our analysis. The negative average value of Rents indicates that Swiss firms burn capital in 2001, on average. ${ }^{22}$ However, the median value is positive and amounts to $2.9 \%$. The mean and the median of Herf are quite similar; 0.412 and 0.409 , respectively. Reg takes on average a value of 1.27 . It has a low of 0.72 for the information technology industry, and a high of 3.26 for the travel industry, which faces the highest market entry regulations. The average value of Tobin's $Q$ is 1.41 , and the median is 1.13 , indicating that Swiss firms, on average, invest in positive NPV projects. Concerning our measure of incentive schemes provided to managers, Sratio, we find that total share-based compensation to officers and directors amounts to $5.7 \%$ of cash-based compensation, on average, while the median value is zero. This quite small values are not surprising as Murphy (1999) shows, that stock (and option) participation plans for the top management are relatively rare in Switzerland and account for a much smaller fraction of total compensation than in most other countries and especially as compared to the US. ${ }^{23}$

Table 2 further shows several other interesting results, which we only briefly summarize: Officers and directors hold on average $16.5 \%$ of the equity of a firm. However, the median of $2.6 \%$ is much smaller, indicating that there are some firms in our sample where officers and directors hold very large fractions of total equity. A comparison of these values to the samples of U.S. firms used by Loderer and Martin (1997) and Anderson et al. (2000) confirms that average insider shareholdings are even slightly higher in Switzerland than in the U.S. However, the median is a lot smaller in our sample and, hence, insider shareholdings are much more skewed in Switzerland. Many other firm characteristics are comparable to those reported by other studies in this area. However, the mean value of Blocko of $28 \%$ is much larger than the value of $7.6 \%$ reported by Anderson et al. (2000) for the U.S. Similarly, the average value of Outsider is $87.9 \%$, which strongly differs from the much lower values of $54 \%$ and 60\% reported by Yermack (1996) and Barnhart et al. (1994), respectively, for U.S. companies and 44\% reported by Peasnell et al. (2003) for U.K. companies. This finding is especially surprising, because founding families are still regarded as an important factor in corporate Switzerland.

\footnotetext{
${ }^{22}$ Two different reasons may be responsible for this somewhat surprising finding. First, 2001 was a worldwide down-market and many firms experienced substantial losses. Second, our measure of profits included in the calculation of Rents $(E B I T D A)$ contains a number of balance sheet items that can potentially distort the economic content of this variable, resulting in values of EBITDA that are downward-biased measures of raw operating surplus (e.g., see Januszewski et al., 2002).

${ }^{23}$ Murphy (1999) compares the level and structure of CEO pay in 23 countries based on data reported in Towers Perrin's 1997 'Worldwide Total Remuneration' report.
} 
[Insert Table 2 about here]

\subsection{Correlations}

Table 3 shows the correlation coefficients between all variables included in the empirical analysis of Section 4. Of special interest are the correlation coefficients between Rents, Herf, Reg, Sratio, and $Q$. Consistent with the implications of our theoretical model, we find a positive correlation coefficient between Rents and $Q$ and a negative and significant coefficient between Rents and Sratio. Based on our theoretical model, this latter result suggests that firms may be operating in competitive environments on average, where more intensive product market competition is associated with stronger incentives provided to managers by increasing the fraction of share-based compensation (see hypothesis 1). The relatively high and statistically significant positive correlation coefficient between Rents and $R O A$ is expected as mentioned in Section 3.1. Consistent with the main hypothesis of Raith (2003), the correlation coefficients between all three competition proxies and Beta and Stdv are negative. Raith (2003) argues that firms operating in an intensive competition environment experience a higher volatility of profits, which, in turn, leads to higher stock price volatility and arguably higher market betas.

With respect to the two other measures of competition, we find a negative correlation coefficient between $\operatorname{Herf}$ and $Q$ and a significant positive relation between $\operatorname{Reg}$ and $Q$, indicating that the different product market competition proxies measure different aspects of competition. The correlation between Herf and Sratio is positive and that between Reg and Sratio negative but both coefficients are not statistically significant. Furthermore, Rents is negatively correlated with Herf and positively correlated with Reg. However, both correlations are weak and not statistically significant, confirming the conjecture that all three proxy variables for competition measure different aspects of product market competition. ${ }^{24}$ Thus, we conclude from this correlation analysis that our empirical investigation should include both firm-level as well as industry-level measures of competition.

Let us finally look at the corporate governance mechanisms. Sratio and Stocksod are positively correlated with $Q$, while Blocko, Leverage, and Outsider are negatively correlated with $Q$. Rents is only very weakly correlated with all corporate governance mechanisms (besides Sratio) and no coefficient is statistically significant. The same is true for Herf and

\footnotetext{
${ }^{24}$ Hence, collinearity problems should not be likely when using all three competition measures simultaneously in the empirical analysis.
} 
Reg with the exception of significant correlation coefficients between Stocksod and Herf and Stocksod and Reg. Sratio is negatively correlated with Blocko indicating possible substitution effects between the monitoring by large outside blockholders and using share-based compensation to tie the personal wealth of officers and directors to their company's performance. As the positive and statistically significant coefficient between Sratio and Lnassets indicates, share-based compensation seems to be more common in large than in small firms. Interestingly, a CEO who is by the same time president of the board seems to be associated with higher values of Sratio as well. Finally and consistent with earlier empirical findings (e.g., see Jensen and Murphy, 1990, or Funk and Wanzenried, 2003), we find a significantly positive correlation coefficient between Sratio and firm performance as measured by the change in shareholder value (CSV).

[Insert Table 3 about here]

\section{Empirical analysis}

\subsection{Comparisons of firms operating in intensive competition environment and other firms}

We begin our empirical analysis by investigating whether there are systematic differences with respect to the variables employed in this study between firms operating in an intensive competition environment and firms which do not. Table 4 presents comparisons of mean and median values between firms with a value of Rents equal to or above the median value (noncompetition firms) and firms with a value of Rents below the median value (competition firms).

Most importantly, we find that non-competition firms have significantly higher values of Tobin's $Q$ than competition firms indicating that the lower economic rents, and therefore profits, associated with a higher product market competition outweigh the potential benefits of reducing managerial slack. This finding is consistent with our third hypothesis. Furthermore and consistent with our theoretical model, Sratio is higher for competition firms. Even though the difference is not statistically significant at any conventional level, this outcome may provide some evidence for our theoretical findings that the relationship between the strength of incentives and the intensity of competition differs depending on the level of product market competition. In particular, it is consistent with our second hypothesis, stating that the relationship between incentives and competition becomes steeper with increasing competition. 
Table 4 furthermore reveals a significantly higher profitability, as measured by $R O A$, of noncompetition firms. This result is expected since $R O A$ and Rents are correlated by construction. ${ }^{25}$ For the same reason, the significantly higher mean and median values of the change in shareholder value CSV, which is also some measure of profitability, of noncompetition firms as compared to competition firms comes as no surprise. The finding of significantly higher leverage ratios of competition firms stands in line with Lord and McIntyre Jr. (2003), who provide evidence for leverage increasing with import competition in the textile and apparel industry. ${ }^{26}$ Finally, competition firms have significantly higher mean and median values of $S t d v$ and Beta. A possible reason for that finding is that firms operating in an intensive competition environment experience a higher volatility of profits (e.g., see Raith, 2003), which, in turn, leads to higher stock price volatility and arguably higher market betas.

[Insert Table 4 about here]

\subsection{Multivariate OLS-regressions}

In this section, we investigate the influence of product market competition on Sratio and Tobin's $Q$ by controlling for different governance mechanisms and control variables in a multivariate regression framework. First, we motivate the regression equation aimed to investigate the determinants of Sratio and report the results of OLS estimations. Then, we examine the effect of competition on Tobin's $Q$.

\subsubsection{The effect of product market competition on incentive schemes}

Since our main interest is to investigate the effect of product market competition on incentive schemes, we include Rents, Herf, or Reg as a first explanatory variable into our regression equation with Sratio as a dependent variable. Because managers are more likely to accept share-based compensation when they are confident that their company will do well and it is beneficial for them to participate on this success, we include Tobin's $Q$ as a forward-looking performance measure of the firm. To investigate whether there are any interrelations between Sratio and other governance mechanisms (e.g., see Beiner et al., 2004), we also include Stocksod, Blocko, Leverage, and Outsider.

\footnotetext{
${ }^{25}$ As Table 3 reveals, the correlation coefficient between ROA and Rents is 0.342 and statistically significant at the $1 \%$ level.

${ }^{26}$ Other work on the relationship between leverage and competition include Brander and Lewis (1986), Maksimovic (1988), Chevalier (1995), Kovenock and Phillips (1995), Phillips (1995), and Zingales (1998).
} 
Besides the measures of product market competition and governance mechanisms, we include four control variables. The first is firm size, Lnassets. Because larger firms operating in an international environment are more likely to adopt share-based compensation, we expect Sratio to be higher for larger firms. As it is standard in the literature on the relationship between pay and performance, we use the change in shareholder value, CSV, as an additional control variable. $C S V$ is expected to have a positive impact on Sratio. In contrast, we expect Sratio to be lower where the costs of the shareholdings are higher. As a measure of these costs, which arise mainly from holding an under-diversified portfolio, we use the standard deviation of 60 monthly returns of a firm's stock, Stdv. Thus, we expect Sratio to be negatively related to $S t d v$. The fourth control variable we include into our regression equation is CEOP. The concentration of power associated with a CEO who is by the same time president of the board may increase the demand for aligned interests. Thus, we expect managers and directors, but especially the CEO, to be compensated by a higher fraction of performance dependent wages. Finally, to control for industry effects, we include eight dummy variables, Industry. Summarizing, the regression equation is:

$$
\begin{aligned}
\text { Sratio }_{i}= & \alpha_{0}+\alpha_{1} \cdot \text { Rents }_{i}+\alpha_{2} \cdot Q_{i}+\alpha_{3} \cdot \text { Stocksod }_{i}+\alpha_{4} \cdot \text { Blocko }_{i}+\alpha_{5} \cdot \text { Leverage }_{i} \\
& +\alpha_{6} \cdot \text { Outsider }_{i}+\alpha_{7} \cdot \text { Lnassets }_{i}+\alpha_{8} \cdot \text { CSV }_{i}+\alpha_{9} \cdot \text { Std }_{i}+\alpha_{10} \cdot \text { CEOP }_{i}+ \\
& \sum_{j=1}^{8} \alpha_{10+j} \cdot \text { Industry }_{i j}+\varepsilon_{i}
\end{aligned}
$$

The results of an OLS estimation of equation 4.1 are reported in Column 1 of Table 5. Consistent with our theoretical model, we find a negative coefficient on Rents indicating that a more intense product market competition is associated with stronger incentive schemes for managers as measured by the fraction of share-based to cash compensation. Therefore, firms operating in a competitive environment seem to provide stronger managerial incentives because competition raises the marginal cost of poor managerial decisions. $Q$ has a positive influence on Sratio indicating that managers are more likely to accept share-based compensation when their company is expected to perform well. This result is consistent with the findings of Chung and Pruitt (1996) who find managers to hold more shares of their company when they are optimistic about its future prospects. However, in contrast to managerial shareholdings of which managers can freely dispose of after a vesting period, it is doubtful that managers have a significant influence on the determination of Sratio and, thus, the coefficient is not statistically significant. Stocksod is also positively but not significantly 
related to Sratio. Thus, firms with already relatively high managerial shareholdings tend to pay higher fractions of share-based compensation to their officers and directors. The significantly negative coefficient on Blocko reveals that monitoring by outside blockholders reduces the demand for incentive alignment of managers and directors. This result is consistent with the findings of Agrawal und Knoeber (1996) and Beiner et al. (2004) that large outside blockholdings are an alternative mechanism for shareholdings by officers and directors. The same seems to be true for Leverage. However, the coefficient is not statistically significant. In contrast, as indicated by the positive and significant coefficient, Outsider seems not to be a substitute for share-based compensation. A higher fraction of outsiders on the board seems to enhance incentive alignments of managers and directors by increasing the ratio of share-based to cash compensation. This result suggests that outside board members encourage share-based compensation contracts.

With respect to the control variables only $C S V$ and $C E O P$ have a significant effect on Sratio. Consistent with Jensen and Murphy (1990) and Funk and Wanzenried (2002), CSV has a positive influence on Sratio indicating a positive relation between the percentage of sharebased to cash compensation and past firm performance. The significantly positive coefficient on $C E O P$ indicates that the concentration of power associated with the CEO being president of the board by the same time, increases the demand for share-based compensation to align the interests between managers and shareholders.

Column 2 of Table 5 reports the results of an OLS regression of equation 4.1, which includes Herf as a measure of product market competition instead of Rents. In contrast to Rents, the coefficient on Herf is positive indicating a negative relation between competition and Sratio. However, the p-value of 0.912 shows that Herf has basically no influence on Sratio. The coefficients on all other variables are robust to replacing Rents by Herf and remain basically unchanged.

The results of an OLS regression of equation 4.1 including Reg as competition proxy are very similar to those obtained for Rents (see Column 3 of Table 5). Again, the coefficient is negative indicating a positive, though not significant, relation between competition and Sratio. All other coefficients are very similar to those reported in Columns 1 and 2 of Table 5.

Since all three competition variables measure different aspects of product market competition, we also estimate equation 4.1 by including all three measures of competition. As the results in Column 4 of Table 5 reveal, the coefficients on Rents and Reg remain negative, but not statistically significant at any conventional level. In contrast to the results reported in Column 
2, the coefficient on Herf is now also negative, indicating a positive relation between competition and incentive schemes provided to managers. The coefficients on all other variables remain basically unchanged. An $F$-test for the simultaneous significance of all coefficients (except the constant and the industry dummies) rejects the null hypothesis that they are jointly zero in all four equations and the adjusted R-squares are between 0.204 and 0.318 .

As a direct test of our hypothesis 2, we separately estimate equation 4.1 for firms in a high and firms in a low competition environment. We split our sample into two subsamples based on the value of Rents. "Competition firms" are firms with a value of Rents below the median value and "non-competition firms" are those firms with a value of Rents equal to or above the median value. Based on hypothesis 2, which states that the marginal effect of competition on the incentives provided to managers increases with the intensity of product market competition, we expect higher coefficients on the competition proxies for "competition firms". In fact, Columns 5 and 6 of Table 5 reveal that the coefficients on all three competition proxies are higher (in absolute terms) for firms operating in a high competition environment than for firms operating in a low competition environment.

The empirical results of this section reveal that in general a more intense product market competition is associated with stronger incentive schemes for managers as measured by the fraction of share-based to cash compensation. This result is consistent with hypothesis 1 and suggests that firms are operating in competitive environments on average. Moreover and consistent with hypothesis 2 , we find the (positive) influence of competition on incentive schemes to be stronger for firms operating in a high competition environment.

[Insert Table 5 about here]

\subsubsection{The effect of competition on firm value}

To test our third hypothesis, which is to examine the effect of product market competition on firm value as measured by Tobin's $Q$, we additionally estimate an OLS regression of $Q$ on the three measures of competition, Rents, Herf, or Reg. Since the additional monitoring on managers associated with a more intense product market competition may be a substitute for incentive schemes and other governance mechanisms, we also include Sratio and the four governance mechanisms, Stocksod, Blocko, Leverage, and Outsider into the regression equation. Finally, we include four control variables. Lnassets and Pgrowth aim to control for 
growth opportunities. Thus, we expect a positive relationship between Pgrowth and $Q$ and a negative influence of Lnassets on $Q$, because growth opportunities tend to be lower for larger firms. Based on simple valuation models, $Q$ may additionally depend on ROA and Beta. Finally, to control for industry effects, we again include eight dummy variables, Industry. Summarizing, the regression equation is:

$$
\begin{aligned}
Q_{i} & =\alpha_{0}+\alpha_{1} \cdot \text { Rents }_{i}+\alpha_{2} \cdot \text { Sratio }_{i}+\alpha_{3} \cdot \text { Stocksod }_{i}+\alpha_{4} \cdot \text { Blocko }_{i}+\alpha_{5} \cdot \text { Leverage }_{i} \\
& +\alpha_{6} \cdot \text { Outsider }_{i}+\alpha_{7} \cdot \text { Lnassets }_{i}+\alpha_{8} \cdot \text { ROA }_{i}+\alpha_{9} \cdot \text { Pgrowth }_{i}+\alpha_{10} \cdot \text { Beta }_{i}+ \\
& +\sum_{j=1}^{8} \alpha_{10+j} \cdot \text { Industry }_{i j}+\varepsilon_{i}
\end{aligned}
$$

The results of estimating equation 4.2 by OLS are reported in Table 6. As Column 1 reveals, Rents has a positive but not statistically significant effect on firm value indicating that a higher product market competition as measured by a firm's rents is associated with a lower firm value. Thus, the negative effect of lower economic rents seems to outweigh the positive effect of reducing managerial slack and increasing the managers' effort by providing additional monitoring and increasing the threat of liquidation. This result is consistent with our third hypothesis. In contrast, Habib and Ljungqvist (2004) provide evidence that firm value is positively related to product market competition.

As Columns 2 and 3 reveal, Herf and Reg have a positive effect on $Q$ as well. However, both coefficients are not statistically significant. Herf measures the market power of the firms in an industry. From standard microeconomic theory it is well known that profits are higher when firms have more market power. As to the level of regulation within an industry concerning new market entrants, Reg, the positive effect is due to the fact that regulations are similar to barriers to entry that protect the incumbents from competition. The positive effect of all three measures of competition is robust to the estimation of a regression equation including Rents, Herf, and Reg (see Column 4).

The coefficients on Sratio, the four governance mechanisms, and the control variables are very similar in all four regression equations. Consistent with the findings of Schmid (2004), Sratio has a positive but not statistically significant effect on firm value. The only statistically significant governance mechanism is Stocksod, which is significantly positively related to 
Tobin's $Q$ in columns (1) and (3). ${ }^{27}$ With respect to the other governance mechanisms, we find negative coefficients on Blocko and Outsider and a positive coefficient on Leverage. The negative effect of Blocko may be due to an entrenchment effect (e.g., see Morck et al., 1988). The coefficient on Outsider is also negative but the $p$-values between 0.544 and 0.632 are quite high. ${ }^{28}$ The positive effect of Leverage is consistent with both a trade-off theory of capital structure and Jensen's (1986) free cash-flow theory. An inspection of the control variables reveals, that Lnassets seems to be unrelated with $Q$ ( $p$-values between 0.895 and 0.998). The coefficients on ROA, Pgrowth, and Beta are all positive, while only ROA and Beta are statistically significant.

An $F$-test for the simultaneous significance of all coefficients (except the constant and the industry dummies) always rejects the null hypothesis that they are jointly zero and the adjusted R-squares between 0.500 and 0.507 are quite high.

The empirical results of this section are consistent with hypothesis 3 of our theoretical model. For all three competition proxies, we find a positive but not statistically significant effect on firm value indicating that a higher product market competition is associated with a lower firm value. Thus, the negative effect of lower economic rents seems to outweigh the positive effect of reducing managerial slack and increasing the managers' effort by providing additional monitoring and increasing the threat of liquidation.

[Insert Table 6 about here]

\subsection{The problem of endogeneity: A simultaneous equations analysis}

A possible concern with respect to our OLS results is that some of our right-hand-side variables are correlated with the error term of the respective equation and, thus, that our results are affected by a possible endogeneity of some of the variables included in our regression equations (e.g., see Agrawal and Knoeber, 1996; and Beiner et al., 2004).

To investigate whether our results suffer from an endogeneity bias, we implement a DurbinWu-Hausman test (e.g., see Hausman, 1978; and Davidson and MacKinnon, 1993) on the endogeneity of Sratio and $Q$. The test involves a two-stage procedure. In the first stage, each

\footnotetext{
${ }^{27}$ The inclusion of a quadratic term of Stocksod reveals that the relation between Stocksod and Tobin's $Q$ is parabolic, but leaves all other results basically unchanged. Empirical evidence on a parabolic relationship between managerial shareholdings and firm value is provided by McConnell and Servaes (1990) and Schmid (2004), for example.

${ }^{28}$ The finding of a negative effect of the fraction of outside directors on the board is consistent with the results of Agrawal and Knoeber (1996), who find Outsider to be the only governance mechanism having a significant influence on Tobin's $Q$. However, they have no plausible explanation for this result.
} 
presumably endogenous variable (i.e., Sratio and $Q$ ) is regressed on all other variables included in the two regression equations. Then, predicted values for the dependent variables are calculated using the estimated coefficients from these first-stage regressions. In the second stage, each dependent variable is regressed on the predicted values of the presumably endogenous variable and the respective right-hand-side variables of that regression equation. The significance of the predicted right-hand-side dependent variable is then tested using a $T$ test with the null hypothesis of no endogeneity.

We report the Durbin-Wu-Hausman test statistics with the respective $p$-values in each Column of Tables 5 and 6 below the OLS results. In no case are we able to reject the null hypothesis of no endogeneity, suggesting that estimating the equations as a simultaneous system is not necessary or appropriate. However, as pointed out by Johnston and DiNardo (1997) among others, the test results can be inconclusive, first, because the test is designed for large samples, and, second, because it may either reflect that the endogeneity bias of the parameters estimated with OLS is not serious or that the predetermined variables excluded from the structural equations are only weakly correlated with the endogenous variables. Following Cohen and Walsh (2000) and notwithstanding the appropriateness of the DurbinWu-Hausman specification test for a relatively small sample such as ours, we check the robustness of our results by estimating both regression equations simultaneously by 3SLS.

The results are reported in Table 7. Panel A presents the estimates for the equation with Sratio as dependent variable and Panel B those for the equation with $Q$ as dependent variable. As a comparison with the OLS results reported in Tables 5 and 6 reveals, the simultaneous estimation of the two equations leaves the majority of the OLS results unchanged. Most importantly, Rents has now a significantly negative influence on Sratio confirming that a more intense product market competition as measured by lower economic rents is associated with stronger incentive schemes for managers (see Panel A). The coefficient of Reg in column 3 stands in line with this finding, even though the result is not significant. Column 4 further shows that the coefficient on Herf is also negative if all three measures of competition are included in the system. Panel B reveals that the effects of Rents, Herf and Reg on $Q$ are still positive confirming that the negative effect of lower economic rents dominates the positive effect of reducing managerial slack and increasing the managers' effort by providing additional monitoring and increasing the threat of liquidation. However, all three coefficients are not statistically significant for equations investigating the effect of each competition proxy separately. In contrast, the inclusion of all three measures of competition into the two equations of the system leads to a coefficient on Herf which is statistically significant at the 
$10 \%$ level. With respect to the corporate governance mechanisms and control variables, there are barely any changes between the OLS and 3SLS estimates. The coefficient of Outsider on Sratio is still positive but not statistically significant any more (Panel A) and the coefficient of Pgrowth on $Q$ is now significant at the $1 \%$ level.

To test for the correctness of the specification of our entire system of simultaneous equations, we apply the Hausman specification test (e.g., see Hausman, 1978; and Hausman, 1983). ${ }^{29}$ As the results in Table 7 reveal, the Hausman test statistic cannot be rejected at the $10 \%$ level for both equations of our system. Thus, under the assumption that at least one of the two equations are correctly specified, the specification of the system of two simultaneous equations cannot be rejected and hence the most efficient estimates can be obtained by applying 3SLS.

[Insert Table 7 about here]

\section{Robustness Tests}

In this section, we investigate the robustness of our empirical results with respect to alternative definitions of the competition variables Rents, Herf, and Reg. With respect to Rents, we employ three additional, alternative definitions. First, we investigate whether our results are robust to the use of 2002 data for the variable Rents, Rents_02. Second, we apply a second measure of Rents based on a rate of depreciation $(\delta)$ of 8 percent (instead of 4 percent), Rents8. Following Nickell (1996), we finally apply an alternative measure of Rents where the equity ratio $(\lambda)$ is set equal to one for all firms, RentsL1. With respect to Herf, we use two alternative measures. Again, the first is based on 2002 data for the calculation of Herf. The second is based on an alternative classification of the relevant industries and uses "market sectors" instead of "industry groups". ${ }^{30}$ Market sectors are defined to be broader than industry sectors leading to a reduction from 33 to 17 industries underlying the calculations of the Herfindahl index. This variable is labeled as Herf_MaSe. Finally, we use an alternative

\footnotetext{
${ }^{29}$ The test statistic of the Hausman specification test is based on a comparison of the 2SLS and 3SLS estimates. Under the null hypothesis of no misspecification, the 3SLS results are consistent and efficient while the 2SLS results are consistent but not efficient. The test investigates for each equation whether the 3SLS results are inconsistent due to a misspecification in one of the other equations. Under 3SLS, the misspecification of one single equation is transmitted to all equations by the use of an inconsistently estimated covariance matrix in the third stage. In contrast, under 2SLS only the single equation that is misspecified is affected by the misspecification. Thus, the crucial assumption of the test is that at least one equation of the system is correctly specified (if this is not the case, 2SLS as well as 3SLS results are inconsistent and the Hausman specification test is not meaningful). If the null is rejected, there is a misspecification somewhere in the system. However, the test does not provide any suggestions about what has to be changed in the system. The Hausman test statistic is distributed Chi-squared with degrees of freedom equal to the number of over-identifying restrictions (the number of instruments included in the system less the number of regressors in the respective equation).

${ }^{30}$ Industry groups as well as market sectors are both based on the classification of the Swiss Exchange (SWX).
} 
definition of Reg, Reg_General, measuring not only the intensity of legal regulations that are specifically relevant for market entry but the level of regulation within the respective industry in general.

To investigate the robustness of our results with respect to these alternative definitions of our competition proxies, we reestimate the regression equations reported in Column 4 of Table 5 (Sratio) and Column 4 of Table $6(Q)$ by OLS. The results in Table 8 reveal that our results with respect to Sratio are robust to replacing any one of the three competition variables (Rents, Herf, and Reg) by one of the alternatives. The use of 2002 data leads to a coefficient on Rents which is statistically significant at the $1 \%$ level. All other coefficients remain basically unchanged. Table 9 reports the results with respect to Tobin's $Q$. Again, the results are quite robust against the use of alternative definitions of the competition variables. Two exceptions are the negative sign on Rents_02 (Column 2) and the negative sign on Herf_MaSe (Column 6). However, both p-values, especially the former, are quite high: 0.875 and 0.476 , respectively.

In general, we conclude that our results are robust to the use of alternative definitions for our three measures of product market competition. However, as already mentioned in Section 3.1.1, our classification of industry groups is arbitrary and may not represent anything like the relevant product market for the firms included in the respective industries. Thus, the finding of a positive coefficient on Herf and a negative on Herf_MaSe may, in fact, suggest that the results with respect to the Herfindahl index depend on the precise definition of the relevant industries.

[Insert Table 8 about here]

[Insert Table 9 about here]

\section{Conclusion}

Our paper is a further contribution to better understand the effects of competition on compensation schemes for managers and on firm valuation. While the theoretical literature offers some insights on this issue, the picture is far from being complete, and more research is clearly needed in this area. Given that the theoretical models often lead to ambiguous results, it seems especially important to provide further empirical evidence on these subjects. This topic has become even more relevant with the increasing influence of public organizations on 
corporate governance rules and the general insight that competition is necessary for a culture of good corporate governance.

In the theoretical section we consider a principal-agent model within a Cournot setup where the manager provides unobservable effort to affect the firm's marginal costs. The key features of our model are as follows: First, it relies on neither on information effects of competition nor on relative performance evaluation. Second, it integrates strategic interaction on product markets between the firms. These features provide an accurate description of firm behavior and lead to testable hypotheses in terms of observable variables.

The empirical part tests the main hypotheses of our theoretical model on the relationship between competition, managerial incentives and firm valuation with data of 156 Swiss companies. Our empirical results reveal that in general a more intense product market competition is associated with stronger incentive schemes for managers as measured by the fraction of share-based to cash compensation. This result is consistent with hypothesis 1 of our theoretical model and suggests that firms are operating in competitive environments on average. Moreover and consistent with hypothesis 2, we find the positive influence of competition on incentive schemes to be stronger for firms operating in a high competition environment. Finally and consistent with hypothesis 3 of our model, we find a positive but not statistically significant effect on firm value for all three competition proxies indicating that a higher product market competition is associated with a lower firm value. Thus, the negative effect of lower economic rents seems to outweigh the positive effect of reducing managerial slack and increasing the managers' effort by providing additional monitoring and increasing the threat of liquidation.

While our work provides some potentially insightful results, it also raises further questions that have to be addressed in future work. It would be interesting to look not only at public companies, but also consider small and medium sized private corporations that build the core part of many economies. More importantly, due to the increasing importance of option-based pay it is obvious that Sratio is an incomplete measure of the incentive schemes provided to officers and directors. ${ }^{31}$ Hence, it would be interesting to enhance our analysis by using the fraction of share- and option-based pay to cash compensation as an alternative, and arguably more complete, measure of the incentive schemes provided to managers. ${ }^{32}$ Also, more detailed compensation and performance data not only from the top, but also from the middle management could be of some interest since some important corporate decisions are taken on

\footnotetext{
${ }^{31}$ Recent evidence on the development of option-based pay in the US is given by Hall and Murphy (2002), for example.

${ }^{32}$ Unfortunately, data on option allotment and ownership is very sparse for Swiss companies in 2002.
} 
this level. Finally, increasing governmental interventions on corporate governance issues call for a good understanding of the role of public policy. 


\section{References}

Aggarwal R.K., and A.A. Samwick, 1999, Executive compensation, strategic competition, and relative performance evaluation: Theory and evidence, Journal of Finance 54, 19992043.

Agrawal A., and C.R. Knoeber, 1996, Firm performance and mechanisms to control agency problems between managers and shareholders, Journal of Financial and Quantitative Analysis 31, 377-397.

Anderson R.C., T.W. Bates, J.M. Bizjak, and M.L. Lemmon, 2000, Corporate governance and firm diversification, Financial Management 78, 5-22.

Barnhart S.W., M.W. Marr, and S. Rosenstein, 1994, Firm performance and board composition: Some new evidence, Managerial and Decision Economics 15, 329-340.

Beiner S., W. Drobetz, M.M. Schmid, and H. Zimmermann, 2004, An integrated framework of corporate governance and firm valuation - Evidence from Switzerland, ECGI - Finance Working Paper No. 34/04.

Boone J., and J. Weigand, 2000, Measuring competition: How are cost differentials mapped into profit differentials? Working Paper No. 131, CPB Netherlands Bureau of Economic Policy Analysis, The Hague.

Brander J., and T. Lewis, 1988, Oligopoly and financial structure: The limited liability effect, American Economic Review 76, 956-970.

Carlin W., and R. Horvath, 2000, Competitive pressures and enterprise performance in transition economies: Conceptual issues and empirical evidence, mimeo.

Chevalier J., 1995, Capital structure and product-market competition: Empirical evidence from the supermarket industry, American Economic Review 85, 415-436.

Chung K.H., and S.W. Pruitt, 1996, Executive ownership, corporate value, and executive compensation - A unifying framework, Journal of Banking and Finance 20, 1135-1159.

Cohen W.M., and J.P. Walsh, 2000, R\&D spillovers, appropriability and R\&D intensity, Working Paper, Carnegie Mellon University and University of Illinois at Chicago.

Cuñat V., and M. Guadalupe, 2004, Executive compensation and competition in the banking and financial sectors, Discussion Paper No. 1123, Institute for the Study of Labor (IZA), Bonn. 
Davidson R., and J. MacKinnon, 1993, Estimation and inference in econometrics, Oxford University Press.

Emons W., and G. Wanzenried, 2003, Neue Regeln guter Unternehmensführung: Eine Analyse aus der Sicht von New Institutional Economics, Wirtschaftsdienst Heft 7, 83. Jahrgang, Hamburgisches Welt-Wirtschafts-Archiv.

Fershtman C., and K.L. Judd, 1987, Equilibrium incentives in oligopolies, American Economic Review 77, 927-940.

Funk P., and G. Wanzenried, 2003, Product market competition and executive compensation: An empirical investigation, Working Paper No. 03.09., Department of Economics University of Bern.

Geroski P., 1990, Innovation, technological opportunity, and market structure, Oxford Econ. Papers 42, 586-602.

Graziano C., and B.M. Parigi, 1998, Do Managers work harder in competitive industries?, Journal of Economic Behavior and Organization 34, 489-498.

Griffith R., 2001, Product market competition, efficiency and agency costs: An empirical analysis, Working Paper 01/12, The Institute for Fiscal Studies.

Grosfeld I., and T. Tressel, 2001, Competition and corporate governance: Substitutes or complements? Evidence from the Warsaw Stock Exchange, mimeo.

Habib M.A., and A. Ljungqvist, 2004, Firm value and managerial incentives: A stochastic frontier approach, Journal of Business (forthcoming).

Hausman J.A., 1978, Specification tests in econometrics, Econometrica 46, 1251-1271.

Hausman J.A., 1983, Specification and estimation of simultaneous equation models, in: Z. Griliches and M. Intriligator (Eds.), Handbook of Econometrics, Volume I (North-Holland: Amsterdam) 391-448.

Hermalin B.E., 1992, The effects of competition on executive behavior, Rand Journal of Economics 23, 350-365.

Januszewski S.I., J. Köke, and J.K. Winter, 2002, Product market competition, corporate governance and firm performance: An empirical analysis for Germany, Research in Economics 56, 299-332.

Jensen M.C., and K.J. Murphy, 1990, Performance pay and top-management incentives, Journal of Political Economy 98, 225-264. 
Joh S.W., 1999, Strategic Managerial incentive compensation in Japan: Relative performance evaluation and product market collusion, Review of Economics and Statistics 81, 303-13.

Johnston J., and J. DiNardo, 1997, Econometric methods, Fourth Edn., New York: McGrawHill.

Kedia S., 2003, Product market competition and top management compensation, Harvard University Working Paper Series, Finance Unit.

Khemani R.S., and C. Leechor, 2001, Competition boots corporate governance, World Bank, Washington, D.C.

Kovenock D., and G. Phillips, 1995, Capital structure and product-market rivalry: How do we reconcile theory and evidence? American Economic Review 85, 403-408.

Ledergerber U., B. Haering, P. Koch, R. Kälin, and R. Eigenmann, 1998, Regelungsdichte nach Branchen, Studienreihe Bundesamt für Wirtschaft und Arbeit, BWA.

Loderer C., and K. Martin, 1997, Executive stock ownership and performance - Tracking faint traces, Journal of Financial Economics 45, 223-255.

Lord R.A., and J.E. McIntyre Jr., 2003, Leverage, imports, profitability, exchange rates, and capital investments: A panel data study of the textile and apparel industries 1974-1987, International Review of Financial Analysis 12, 287-310.

Machlup F., 1967, Theories of the firm: Marginalist, behavioral, managerial, American Economic Review 57, 1-33.

Maksimovic V., 1988, Capital structure in repeated oligopolies, Rand Journal of Economics 19, 389-408.

McConnell J., and H. Servaes, 1990, Additional evidence on equity ownership and corporate value, Journal of Financial Economics 27, 595-613.

Morck R., A. Shleifer, and R. Vishny, 1988, Management ownership and market valuation An empirical analysis, Journal of Financial Economics 20, 293-316.

Murphy K.J., 1999, Executive compensation, in: O. Ashenfelter and D. Card (Eds.), Handbook of Labor Economics, Volume 3, (North-Holland: Amsterdam).

Nickell S.J., 1996, Competition and corporate performance, Journal of Political Economy 104, 724-746.

Nickell S.J., D. Nicolitsas, and N. Dryden, 1997, What makes firms perform well?, European Economic Review 41, 783-796. 
Ogus A. I., 1994, Regulation - legal form and economic theory, Oxford University Press, Oxford.

Peasnell K.V., P.F. Pope, and S. Young, 2003, Managerial equity ownership and the demand for outside directors, European Financial Management 9, 231-250.

Phillips G., 1995, Increaded debt and industry product markets. An empirical analysis, Journal of Financial Economics 37, 189-238.

Raith M., 2003, Competition, risk and managerial incentives, American Economic Review 93, 1425-1436.

Salas Fumas V., 1992, Relative performance evaluation of management: The effects on industrial competition and risk sharing, International Journal of Industrial Organization 10, 473-489.

Scharfstein, D., 1988, Product market competition and managerial slack, Rand Journal of Economics 19, 147-155.

Schmid M.M., 2004, Managerial incentives and firm valuation - Evidence from Switzerland, Working Paper, University of Basel.

Schmidt K., 1997, Managerial incentives and product market competition, Review of Economic Studies 64, 191-213.

Sklivas S., 1987, The strategic choice of managerial incentives, Rand Journal of Economics $18,452-458$.

Vickers J., 1985, Delegation and the theory of the firm, Economic Journal 95, 138-147.

Yermack D., 1996, Higher market valuation of companies with a small board of directors, Journal of Financial Economics 40, 185-211.

Zingales L., 1998, Survival of the fittest or the fattest? Exit and financing in the trucking industry, Journal of Finance 53, 905-938. 


\section{Table 1: Definition of variables}

\begin{tabular}{|c|c|}
\hline Rents & $\begin{array}{l}\text { Measure of ex-post monopoly power defined as profits before interest payments, tax, and } \\
\text { depreciation minus the costs of capital multiplied by total assets and standardized by the } \\
\text { company's sales }\end{array}$ \\
\hline Herf & A sales-based Herfindahl index \\
\hline $\operatorname{Reg}$ & Measure of the intensity of regulation by federal law for entering a new market \\
\hline Q & $\begin{array}{l}\text { Ratio of market value to book value of assets. Market value of assets is computed as } \\
\text { market value of equity plus book value of assets minus book value of equity. }\end{array}$ \\
\hline Sratio & Fraction of share-based to cash compensation to the firm's officers and directors \\
\hline Stocksod & Percentage of equity owned by officers and directors \\
\hline Blocko & $\begin{array}{l}\text { Percentage of cumulated voting rights exercised by large investors with }>5 \% \text { of voting } \\
\text { rights (excluding officers, directors, and related persons) }\end{array}$ \\
\hline Leverage & Leverage, measured as the ratio of total (non-equity) liabilities to total assets \\
\hline Outsider & $\begin{array}{l}\text { Outsider membership on the board, measured by the percentage of board seats held by } \\
\text { non-officers without relationship to the founding family (if any) }\end{array}$ \\
\hline Lnassets & Firm size, measured by the natural logarithm of book value of total assets \\
\hline$R O A$ & Return on assets, defined as the ratio of operating income to total assets \\
\hline Pgrowth & Average annual growth of sales over the past three years (2000-2002) \\
\hline CSV & $\begin{array}{l}\text { Change in shareholder value in million CHF as measured by the return on equity multiplied } \\
\text { by the market value of equity in the previous period }\end{array}$ \\
\hline Stdv & Standard deviation of stock returns, estimated from 60 monthly stock returns \\
\hline Beta & Beta, estimated from 60 monthly stock returns \\
\hline CEOP & 1 , if the CEO is also the president of the board; 0 otherwise \\
\hline Industry & 9 industry dummy variables \\
\hline
\end{tabular}

This table provides definitions of all variables included in the empirical investigations of this study (Sections 4 and 5). Alternative measures of product market competition are defined in Section 5 investigating the robustness of our results. 
Table 2: Summary statistics of variables

\begin{tabular}{lrrrrr}
\hline & Mean & Median & Maximum & Minimum & Std. Dev. \\
& & & & & \\
\hline Rents & -0.042 & 0.029 & 5.672 & -5.680 & 0.733 \\
Herf & 0.412 & 0.409 & 1.000 & 0.131 & 0.230 \\
Reg & 1.274 & 1.0160 & 3.257 & 0.724 & 0.552 \\
\hline Q & 1.415 & 1.130 & 7.710 & 0.581 & 0.918 \\
Sratio & 0.057 & 0.000 & 0.878 & 0.000 & 0.142 \\
Stocksod & 0.165 & 0.026 & 0.858 & 0.000 & 0.224 \\
Blocko & 0.280 & 0.198 & 1.000 & 0.000 & 0.271 \\
Leverage & 0.578 & 0.587 & 1.138 & 0.074 & 0.213 \\
Outsider & 0.879 & 0.875 & 1.000 & 0.400 & 0.133 \\
\hline Lnassets & 13.638 & 13.431 & 20.890 & 10.083 & 1.742 \\
ROA & 0.024 & 0.046 & 0.334 & -0.610 & 0.122 \\
Pgrowth & 0.157 & 0.060 & 3.973 & -0.624 & 0.466 \\
CSV & 0.909 & 0.038 & 32.728 & -2.430 & 4.231 \\
Stdv & 0.394 & 0.342 & 1.118 & 0.057 & 0.204 \\
Beta & 0.863 & 0.790 & 3.279 & -0.224 & 0.582 \\
CEOP & 0.192 & 0.000 & 1.000 & 0.000 & 0.395 \\
\hline
\end{tabular}

This table reports the summary statistics of all variables included in the empirical investigations of this study (Section 4), with the exception of Industry and the alternative measures of product market competition employed in the robustness section. The variables are the following: A measure of ex-post rents (Rents), sales-based Herfindahl index (Herf), level of regulations for market entry (Reg), Tobin's $Q(Q)$, ratio of share-based to cash compensation (Sratio), the percentage of equity owned by officers and directors (Stocksod), cumulated voting rights by outside blockholders (Blocko), leverage (Leverage), the fraction of outside directors on the board (Outsider), log of book value of total assets (Lnassets), return on assets $(R O A)$, average annual sales growth over the past three years (Pgrowth), change in shareholder value (CSV), standard deviation of stock returns (Stdv), market beta (Beta), and a dummy variable whether the CEO is also the president of the board (CEOP). The data generally refers to the reporting period from January 2002 to December 2002 and the sample size is 156 . 
Table 3: Correlation analysis

\begin{tabular}{|c|c|c|c|c|c|c|c|c|c|c|c|c|c|c|c|}
\hline & Rents & Hert & Reg & $Q$ & Sratio & Stocksod & Blocko & Leverage & Outsider & Lnassets & $R O A$ & Pgrowth & csv & $S t d v$ & Beta \\
\hline Herf & $\begin{array}{r}-0.1005 \\
0.2119\end{array}$ & & & & & & & & & & & & & & \\
\hline Reg & $\begin{array}{l}0.0721 \\
0.3713\end{array}$ & $\begin{array}{l}0.1579^{* *} \\
0.0490\end{array}$ & & & & & & & & & & & & & \\
\hline$Q$ & $\begin{array}{l}0.0353 \\
0.6614\end{array}$ & $\begin{array}{r}-0.0513 \\
0.5250\end{array}$ & $\begin{array}{l}0.1890^{* *} \\
0.0181\end{array}$ & & & & & & & & & & & & \\
\hline Sratio & $\begin{array}{l}-0.3068^{\text {*** }} \\
0.0001\end{array}$ & $\begin{array}{l}0.0804 \\
0.3181\end{array}$ & $\begin{array}{r}-0.0142 \\
0.8602\end{array}$ & $\begin{array}{l}0.0622 \\
0.4403\end{array}$ & & & & & & & & & & & \\
\hline Stocksod & $\begin{array}{r}-0.0845 \\
0.2945\end{array}$ & $\begin{array}{l}0.1569^{*} \\
0.0504\end{array}$ & $\begin{array}{l}0.1531^{*} \\
0.0564\end{array}$ & $\begin{array}{l}0.1438^{*} \\
0.0734\end{array}$ & $\begin{array}{r}-0.0027 \\
0.9738\end{array}$ & & & & & & & & & & \\
\hline Blocko & $\begin{array}{l}0.0515 \\
0.5232\end{array}$ & $\begin{array}{l}0.0273 \\
0.7354\end{array}$ & $\begin{array}{r}-0.0545 \\
0.4989\end{array}$ & $\begin{array}{l}-0.1705^{\text {** }} \\
0.0334\end{array}$ & $\begin{array}{l}-0.1860^{* *} \\
0.0201\end{array}$ & $\begin{array}{l}-0.2775^{* * *} \\
0.0005\end{array}$ & & & & & & & & & \\
\hline Leverage & $\begin{array}{r}-0.0647 \\
0.4222\end{array}$ & $\begin{array}{l}0.1045 \\
0.1941\end{array}$ & $\begin{array}{r}-0.0996 \\
0.2162\end{array}$ & $\begin{array}{l}-0.2166^{* * *} \\
0.0066\end{array}$ & $\begin{array}{l}0.0279 \\
0.7293\end{array}$ & $\begin{array}{l}-0.2793^{* * *} \\
0.0004\end{array}$ & $\begin{array}{l}0.2583^{* * *} \\
0.0011\end{array}$ & & & & & & & & \\
\hline Outsider & $\begin{array}{l}0.0787 \\
0.3290\end{array}$ & $\begin{array}{r}-0.0343 \\
0.6705\end{array}$ & $\begin{array}{l}0.0478 \\
0.5531\end{array}$ & $\begin{array}{r}-0.0533 \\
0.5088\end{array}$ & $\begin{array}{l}0.0599 \\
0.4574\end{array}$ & $\begin{array}{l}-0.1986^{* *} \\
0.0130\end{array}$ & $\begin{array}{l}0.0901 \\
0.2635\end{array}$ & $\begin{array}{l}0.2330^{* * *} \\
0.0034\end{array}$ & & & & & & & \\
\hline Lnassets & $\begin{array}{r}-0.0744 \\
0.3560\end{array}$ & $\begin{array}{l}0.0527 \\
0.5133\end{array}$ & $\begin{array}{l}0.0935 \\
0.2458\end{array}$ & $\begin{array}{l}0.0723 \\
0.3697\end{array}$ & $\begin{array}{l}0.2915^{* * *} \\
0.0002\end{array}$ & $\begin{array}{l}-0.2485^{* * *} \\
0.0018\end{array}$ & $\begin{array}{l}0.0481 \\
0.5512\end{array}$ & $\begin{array}{l}0.4067^{* * *} \\
0.0000\end{array}$ & $\begin{array}{l}0.2997^{* * *} \\
0.0001\end{array}$ & & & & & & \\
\hline$R O A$ & $\begin{array}{l}0.3420^{* \star *} \\
0.0000\end{array}$ & $\begin{array}{r}-0.0887 \\
0.2709\end{array}$ & $\begin{array}{l}0.1310 \\
0.1031\end{array}$ & $\begin{array}{l}0.2308^{* \star *} \\
0.0038\end{array}$ & $\begin{array}{l}0.0004 \\
0.9965\end{array}$ & $\begin{array}{r}-0.0330 \\
0.6823\end{array}$ & $\begin{array}{r}-0.0657 \\
0.4149\end{array}$ & $\begin{array}{r}-0.0302 \\
0.7084\end{array}$ & $\begin{array}{l}0.1754^{* *} \\
0.0285\end{array}$ & $\begin{array}{l}0.2612^{* * *} \\
0.0010\end{array}$ & & & & & \\
\hline Pgrowth & $\begin{array}{c}-0.1356^{*} \\
0.0914\end{array}$ & $\begin{array}{r}-0.0821 \\
0.3082\end{array}$ & $\begin{array}{l}0.0029 \\
0.9711\end{array}$ & $\begin{array}{l}0.2705^{* \star *} \\
0.0006\end{array}$ & $\begin{array}{r}-0.0152 \\
0.8510\end{array}$ & $\begin{array}{r}-0.0332 \\
0.6804\end{array}$ & $\begin{array}{l}0.0745 \\
0.3556\end{array}$ & $\begin{array}{r}-0.0576 \\
0.4749\end{array}$ & $\begin{array}{l}0.0071 \\
0.9304\end{array}$ & $\begin{array}{r}-0.0015 \\
0.9854\end{array}$ & $\begin{array}{r}-0.1203 \\
0.1348\end{array}$ & & & & \\
\hline $\operatorname{csv}$ & $\begin{array}{r}-0.0267 \\
0.7406\end{array}$ & $\begin{array}{l}0.1599^{* *} \\
0.0461\end{array}$ & $\begin{array}{l}0.1633^{* *} \\
0.0416\end{array}$ & $\begin{array}{l}0.2438^{* * *} \\
0.0022\end{array}$ & $\begin{array}{l}0.4169^{* * *} \\
0.0000\end{array}$ & $\begin{array}{r}-0.0946 \\
0.2399\end{array}$ & $\begin{array}{r}-0.0758 \\
0.3469\end{array}$ & $\begin{array}{l}0.0134 \\
0.8683\end{array}$ & $\begin{array}{l}0.0643 \\
0.4249\end{array}$ & $\begin{array}{l}0.5071^{* * *} \\
0.0000\end{array}$ & $\begin{array}{l}0.1376^{*} \\
0.0867\end{array}$ & $\begin{array}{r}-0.0583 \\
0.4694\end{array}$ & & & \\
\hline Stdv & $\begin{array}{l}-0.2225^{\text {*** }} \\
0.0052\end{array}$ & $\begin{array}{c}-0.1516^{*} \\
0.0588\end{array}$ & $\begin{array}{l}-0.2002^{* *} \\
0.0122\end{array}$ & $\begin{array}{l}0.1612^{* *} \\
0.0444\end{array}$ & $\begin{array}{r}-0.0099 \\
0.9019\end{array}$ & $\begin{array}{l}0.0789 \\
0.3277\end{array}$ & $\begin{array}{l}-0.1595^{\star \star} \\
0.0467\end{array}$ & $\begin{array}{l}-0.1624^{* *} \\
0.0428\end{array}$ & $\begin{array}{l}-0.3149^{* * *} \\
0.0001\end{array}$ & $\begin{array}{l}-0.3435^{* \star *} \\
0.0000\end{array}$ & $\begin{array}{l}-0.5362^{* \star *} \\
0.0000\end{array}$ & $\begin{array}{l}0.0859 \\
0.2866\end{array}$ & $\begin{array}{c}-0.1515^{*} \\
0.0590\end{array}$ & & \\
\hline Beta & $\begin{array}{r}-0.0152 \\
0.8504\end{array}$ & $\begin{array}{l}-0.1730^{\star *} \\
0.0308\end{array}$ & $\begin{array}{l}-0.1509^{*} \\
0.0601\end{array}$ & $\begin{array}{l}0.2480^{* * *} \\
0.0018\end{array}$ & $\begin{array}{r}-0.0107 \\
0.8946\end{array}$ & $\begin{array}{l}0.0337 \\
0.6765\end{array}$ & $\begin{array}{l}-0.2288^{* * *} \\
0.0041\end{array}$ & $\begin{array}{r}-0.0872 \\
0.2790\end{array}$ & $\begin{array}{r}-0.1030 \\
0.2008\end{array}$ & $\begin{array}{l}0.0004 \\
0.9963\end{array}$ & $\begin{array}{l}-0.2810^{* * *} \\
0.0004\end{array}$ & $\begin{array}{l}0.0744 \\
0.3563\end{array}$ & $\begin{array}{r}-0.0266 \\
0.7416\end{array}$ & $\begin{array}{l}0.7239^{* * *} \\
0.0000\end{array}$ & \\
\hline CEOP & $\begin{array}{r}-0.0389 \\
0.6297\end{array}$ & $\begin{array}{l}0.0003 \\
0.9975\end{array}$ & $\begin{array}{r}-0.0329 \\
0.6833\end{array}$ & $\begin{array}{l}0.0956 \\
0.2349\end{array}$ & $\begin{array}{l}0.1959^{* *} \\
0.0142\end{array}$ & $\begin{array}{l}0.0747 \\
0.3543\end{array}$ & $\begin{array}{r}-0.0615 \\
0.4455\end{array}$ & $\begin{array}{l}-0.1520^{*} \\
0.0582\end{array}$ & $\begin{array}{l}-0.4045^{* * *} \\
0.0000\end{array}$ & $\begin{array}{r}-0.0101 \\
0.9004\end{array}$ & $\begin{array}{r}-0.0084 \\
0.9167\end{array}$ & $\begin{array}{l}0.0295 \\
0.7144\end{array}$ & $\begin{array}{l}0.1400^{*} \\
0.0812\end{array}$ & $\begin{array}{l}0.1797^{* *} \\
0.0248\end{array}$ & $\begin{array}{l}0.0957 \\
0.2349\end{array}$ \\
\hline
\end{tabular}

This table reports Pearson correlation coefficients between all variables included in the empirical investigations of this study (Section 4), with the exception of Industry and the alternative measures of product market competition employed in the robustness section. The variables are the following: A measure of ex-post rents (Rents), sales-based Herfindahl index (Herf), level of regulations for market entry (Reg), Tobin's $Q(Q)$, ratio of share-based to cash compensation (Sratio), the percentage of equity owned by officers and directors (Stocksod), cumulated voting rights by outside blockholders (Blocko), leverage (Leverage), the fraction of outside directors on the board (Outsider), log of book value of total assets (Lnassets), return on assets (ROA), average annual sales growth over the past three years (Pgrowth), change in shareholder value (CSV), standard 
deviation of stock returns (Stdv), market beta (Beta), and a dummy variable whether the CEO is also the president of the board (CEOP). The data generally refers to the reporting period from January 2002 to December 2002 and the sample size is 156 . The p-values are in parentheses. $* * * / * * *$ denotes statistical significance at the $1 \% / 5 \% / 10 \%$ level. 
Table 4: Comparisons of firms "operating in intensive competition environment" and other firms

\begin{tabular}{|c|c|c|c|c|c|c|c|c|}
\hline & \multicolumn{2}{|c|}{ Competition Firms } & \multicolumn{2}{|c|}{ Non-Competition Firms } & \multicolumn{2}{|c|}{ Difference } & \multicolumn{2}{|c|}{ Difference } \\
\hline & Mean & Median & Mean & Median & Mean & t-test & Median & Wilcoxon \\
\hline$Q$ & 1.205 & 1.025 & 1.625 & 1.254 & -0.420 & $0.004^{* * *}$ & -0.229 & $0.000^{* * *}$ \\
\hline Sratio & 0.061 & 0.000 & 0.053 & 0.000 & 0.008 & 0.719 & 0.000 & 0.698 \\
\hline Stocksod & 0.154 & 0.013 & 0.176 & 0.050 & -0.023 & 0.529 & -0.036 & 0.402 \\
\hline Blocko & 0.292 & 0.228 & 0.267 & 0.161 & 0.025 & 0.564 & 0.068 & 0.299 \\
\hline Leverage & 0.621 & 0.633 & 0.536 & 0.552 & 0.085 & $0.013^{* *}$ & 0.081 & $0.008^{* * *}$ \\
\hline Outsider & 0.870 & 0.866 & 0.888 & 0.888 & -0.018 & 0.391 & -0.021 & 0.546 \\
\hline Beta & 1.005 & 0.992 & 0.722 & 0.650 & 0.283 & $0.002^{* * *}$ & 0.342 & $0.007^{* * *}$ \\
\hline CEOP & 0.192 & 0.000 & 0.192 & 0.000 & 0.000 & 1.000 & 0.000 & 0.999 \\
\hline CSV & 0.306 & 0.013 & 1.513 & 0.081 & -1.207 & $0.075^{*}$ & -0.068 & $0.000^{* * *}$ \\
\hline Lnassets & 13.577 & 13.409 & 13.700 & 13.494 & -0.124 & 0.659 & -0.085 & 0.539 \\
\hline Pgrowth & 0.156 & 0.035 & 0.158 & 0.063 & -0.003 & 0.970 & -0.028 & $0.007^{* * *}$ \\
\hline$R O A$ & -0.023 & 0.017 & 0.071 & 0.073 & -0.094 & $0.000^{* * *}$ & -0.056 & $0.000^{* * *}$ \\
\hline Stdv & 0.448 & 0.397 & 0.340 & 0.305 & 0.108 & $0.001^{* * *}$ & 0.091 & $0.001^{* * *}$ \\
\hline
\end{tabular}

This table presents comparisons of mean and median Tobin's $Q(Q)$, ratio of share-based to cash compensation (Sratio), percentage of equity owned by officers and directors (Stocksod), cumulated voting rights by outside blockholders (Blocko), leverage (Leverage), the fraction of outside directors on the board (Outsider), log of book value of total assets (Lnassets), return on assets (ROA), average annual sales growth over the past three years (Pgrowth), change in shareholder value $(C S V)$, standard deviation of stock returns $(S t d v)$, market beta $($ Beta), and a dummy variable whether the CEO is also the president of the board (CEOP) between firms with a value of Rents equal to or above the median value (non-competition firms) and firms with a value of Rents below the median value (competition firms). Equality of means is tested using a standard t-test and equality of medians is tested using a Wilcoxon signed rank test. The table reports p-values. $* * * / * * / *$ denotes statistical significance at the $1 \% / 5 \% / 10 \%$ level 
Table 5: Results from OLS regressions of Sratio on different measures of product market competition

\begin{tabular}{|c|c|c|c|c|c|c|}
\hline & \multicolumn{6}{|c|}{ Dependent Variable $=$ Sratio } \\
\hline & (1) & $(2)$ & $(3)$ & $(4)$ & $(5)$ & (6) \\
\hline \multirow[t]{2}{*}{ C } & -0.095 & -0.119 & -0.111 & -0.070 & $-0.280^{*}$ & -0.097 \\
\hline & 0.518 & 0.408 & 0.462 & 0.635 & 0.062 & 0.740 \\
\hline \multirow[t]{2}{*}{ Rents } & -0.065 & & & -0.068 & $-0.143^{* * *}$ & -0.044 \\
\hline & 0.108 & & & 0.106 & 0.001 & 0.274 \\
\hline \multirow[t]{2}{*}{ Herf } & & 0.006 & & -0.050 & $-0.176^{* * *}$ & 0.092 \\
\hline & & 0.912 & & 0.255 & 0.005 & 0.497 \\
\hline \multirow[t]{2}{*}{$\operatorname{Reg}$} & & & -0.008 & -0.008 & -0.043 & 0.030 \\
\hline & & & 0.686 & 0.689 & 0.137 & 0.359 \\
\hline \multirow[t]{2}{*}{$Q$} & 0.007 & -0.002 & -0.002 & 0.008 & 0.005 & 0.006 \\
\hline & 0.525 & 0.840 & 0.835 & 0.504 & 0.829 & 0.678 \\
\hline \multirow[t]{2}{*}{ Stocksod } & 0.008 & 0.029 & 0.032 & 0.018 & 0.046 & 0.015 \\
\hline & 0.792 & 0.427 & 0.453 & 0.541 & 0.306 & 0.742 \\
\hline \multirow[t]{2}{*}{ Blocko } & $-0.088^{* *}$ & $-0.092^{* *}$ & $-0.092^{* *}$ & $-0.085^{* *}$ & -0.018 & -0.130 \\
\hline & 0.033 & 0.031 & 0.029 & 0.037 & 0.645 & 0.154 \\
\hline \multirow[t]{2}{*}{ Leverage } & -0.034 & -0.020 & -0.020 & -0.033 & 0.038 & 0.031 \\
\hline & 0.526 & 0.733 & 0.728 & 0.542 & 0.579 & 0.760 \\
\hline \multirow[t]{2}{*}{ Outsider } & $0.130^{* *}$ & $0.127^{* \star}$ & $0.124^{* *}$ & $0.121^{* *}$ & $0.145^{*}$ & 0.190 \\
\hline & 0.026 & 0.032 & 0.039 & 0.038 & 0.095 & 0.208 \\
\hline \multirow[t]{2}{*}{ Lnassets } & 0.002 & 0.004 & 0.004 & 0.003 & 0.011 & -0.005 \\
\hline & 0.808 & 0.697 & 0.662 & 0.784 & 0.397 & 0.667 \\
\hline \multirow[t]{2}{*}{ CSV } & $0.014^{* *}$ & $0.014^{* *}$ & $0.014^{* *}$ & $0.014^{* *}$ & $0.027^{* * *}$ & 0.011 \\
\hline & 0.045 & 0.044 & 0.046 & 0.042 & 0.000 & 0.112 \\
\hline \multirow[t]{2}{*}{$S t d v$} & 0.083 & 0.102 & 0.103 & 0.086 & 0.021 & -0.022 \\
\hline & 0.235 & 0.174 & 0.183 & 0.216 & 0.737 & 0.869 \\
\hline \multirow[t]{2}{*}{ CEOP } & $0.070^{* *}$ & $0.066^{*}$ & $0.064^{*}$ & $0.067^{* *}$ & 0.090 * & $0.102^{* *}$ \\
\hline & 0.026 & 0.060 & 0.085 & 0.038 & 0.061 & 0.039 \\
\hline Industry & included & included & included & included & included & Included \\
\hline Adjusted $\mathrm{R}^{2}$ & 0.318 & 0.204 & 0.204 & 0.313 & 0.487 & 0.279 \\
\hline F-statistic & 3.026 *** & $2.987^{* * *}$ & $2.993 * * *$ & $2.531^{\star * *}$ & $8.294^{* * *}$ & 1.506 \\
\hline Prob(F-statistic) & 0.002 & 0.002 & 0.002 & 0.005 & 0.000 & 0.149 \\
\hline $\begin{array}{l}\text { Durbin-Wu- } \\
\text { Hausman }\end{array}$ & 0.017 & 0.715 & 0.642 & 0.104 & & \\
\hline Prob(D-W-H) & 0.895 & 0.399 & 0.424 & 0.748 & & \\
\hline $\mathrm{N}$ & 156 & 156 & 156 & 156 & 78 & 78 \\
\hline
\end{tabular}

Columns 1 to 4 report estimates from OLS regressions of the percentage of share-based to cash compensation (Sratio) on individual measures of product market competition (Rents, Herf, and Reg) and all three measures together along with Tobin's $Q(Q)$, four corporate governance mechanisms (Stocksod, Blocko, Leverage, and Outsider), and four control variables (Lnassets, CSV, Stdv, and $C E O P$ ). Columns 5 and 6 report OLS estimates for firms operating in a high and firms operating in a low competition environment. "Competition firms" (Column 5) are firms with a value of Rents below the median value and "non-competition firms" (Column 6) are firms with a value of Rents equal to or above the median value. An $F$-test is performed for the simultaneous significance of all coefficients (except the constant and industry dummies). The numbers in parentheses are probability values for two-sided tests. $* * * / * * / *$ denotes statistical significance at the $1 \% / 5 \% / 10 \%$ level. 
Table 6: Results from OLS regressions of Tobin's $Q$ on different measures of product market competition

\begin{tabular}{|c|c|c|c|c|}
\hline & \multicolumn{4}{|c|}{ Dependent Variable $=$ Tobin's $Q$} \\
\hline & $(1)$ & $(2)$ & (3) & $(4)$ \\
\hline \multirow[t]{2}{*}{$C$} & 0.962 & 0.925 & 0.971 & 0.856 \\
\hline & 0.123 & 0.137 & 0.116 & 0.166 \\
\hline \multirow[t]{2}{*}{ Rents } & 0.053 & & & 0.072 \\
\hline & 0.625 & & & 0.472 \\
\hline \multirow[t]{2}{*}{ Herf } & & 0.415 & & 0.457 \\
\hline & & 0.147 & & 0.108 \\
\hline \multirow[t]{2}{*}{$\operatorname{Reg}$} & & & 0.062 & 0.068 \\
\hline & & & 0.585 & 0.525 \\
\hline \multirow[t]{2}{*}{ Sratio } & 0.292 & 0.189 & 0.222 & 0.323 \\
\hline & 0.348 & 0.437 & 0.390 & 0.283 \\
\hline \multirow[t]{2}{*}{ Stocksod } & $0.517^{*}$ & 0.437 & $0.492^{*}$ & 0.429 \\
\hline & 0.053 & 0.104 & 0.064 & 0.107 \\
\hline \multirow[t]{2}{*}{ Blocko } & -0.235 & -0.246 & -0.232 & -0.244 \\
\hline & 0.221 & 0.195 & 0.223 & 0.206 \\
\hline \multirow[t]{2}{*}{ Leverage } & 0.384 & 0.381 & 0.381 & 0.402 \\
\hline & 0.210 & 0.214 & 0.221 & 0.192 \\
\hline \multirow[t]{2}{*}{ Outsider } & -0.248 & -0.217 & -0.262 & -0.208 \\
\hline & 0.565 & 0.614 & 0.544 & 0.632 \\
\hline \multirow[t]{2}{*}{ Lnassets } & 0.006 & -0.003 & 0.000 & -0.007 \\
\hline & 0.912 & 0.953 & 0.998 & 0.895 \\
\hline \multirow[t]{2}{*}{$R O A$} & $1.975^{* *}$ & $2.257^{* *}$ & $2.103^{* *}$ & 2.170 ** \\
\hline & 0.036 & 0.012 & 0.016 & 0.026 \\
\hline \multirow[t]{2}{*}{ Pgrowth } & 0.357 & 0.358 & 0.343 & 0.376 \\
\hline & 0.129 & 0.111 & 0.139 & 0.101 \\
\hline \multirow[t]{2}{*}{ Beta } & $0.287^{* *}$ & $0.315^{* *}$ & $0.307^{* *}$ & $0.292^{* *}$ \\
\hline & 0.048 & 0.029 & 0.031 & 0.050 \\
\hline Industry & included & included & included & included \\
\hline Adjusted $\mathrm{R}^{2}$ & 0.501 & 0.507 & 0.500 & 0.503 \\
\hline F-statistic & 2.868 & 2.649 & 2.580 & 2.483 \\
\hline Prob(F-statistic) & 0.003 & 0.006 & 0.007 & 0.006 \\
\hline $\begin{array}{l}\text { Durbin-Wu- } \\
\text { Hausman }\end{array}$ & $0 \Omega 63$ & م, & 187 & 0030 \\
\hline $\operatorname{Prob}(\mathrm{D}-\mathrm{W}-\mathrm{H})$ & 0.802 & 0.808 & 0.666 & 0.863 \\
\hline
\end{tabular}

Estimates from OLS regressions of Tobin's $Q(Q)$ on individual measures of product market competition (Rents, Herf, and Reg) and all three measures together along with the percentage of share-based to cash compensation (Sratio), four corporate governance mechanisms (Stocksod, Blocko, Leverage, and Outsider), and four control variables (Lnassets, ROA, Pgrowth, and Beta). The sample size is 156. An F-test is performed for the simultaneous significance of all coefficients (except the constant and industry dummies). The numbers in parentheses are probability values for two-sided tests. $* * * / * * * *$ denotes statistical significance at the $1 \% / 5 \% / 10 \%$ level. 
Table 7: Results from 3SLS estimations of the simultaneous equations system

\begin{tabular}{|c|c|c|c|c|}
\hline & \multicolumn{4}{|c|}{ Panel A: Dependent Variable $=$ Sratio } \\
\hline & 1 & 2 & 3 & 4 \\
\hline \multirow[t]{2}{*}{ C } & -0.089 & -0.108 & -0.096 & -0.064 \\
\hline & 0.517 & 0.478 & 0.527 & 0.646 \\
\hline \multirow[t]{2}{*}{ Rents } & $-0.065^{* * *}$ & & & $-0.067^{* * *}$ \\
\hline & 0.000 & & & 0.000 \\
\hline \multirow[t]{2}{*}{ Herf } & & 0.009 & & -0.049 \\
\hline & & 0.868 & & 0.332 \\
\hline \multirow[t]{2}{*}{$\operatorname{Reg}$} & & & -0.008 & -0.008 \\
\hline & & & 0.745 & 0.722 \\
\hline \multirow[t]{2}{*}{ Q } & 0.003 & -0.037 & -0.040 & -0.002 \\
\hline & 0.920 & 0.278 & 0.261 & 0.942 \\
\hline \multirow[t]{2}{*}{ Stocksod } & 0.010 & 0.045 & 0.050 & 0.023 \\
\hline & 0.834 & 0.386 & 0.335 & 0.629 \\
\hline \multirow[t]{2}{*}{ Blocko } & $-0.089 * *$ & $-0.104^{* *}$ & $-0.104^{* *}$ & $-0.089 * *$ \\
\hline & 0.034 & 0.024 & 0.023 & 0.035 \\
\hline \multirow[t]{2}{*}{ Leverage } & -0.033 & -0.017 & -0.017 & -0.032 \\
\hline & 0.560 & 0.787 & 0.788 & 0.580 \\
\hline \multirow[t]{2}{*}{ Outsider } & 0.126 & 0.126 & 0.121 & 0.118 \\
\hline & 0.126 & 0.164 & 0.182 & 0.155 \\
\hline \multirow[t]{2}{*}{ Lnassets } & 0.003 & 0.006 & 0.007 & 0.003 \\
\hline & 0.757 & 0.483 & 0.446 & 0.679 \\
\hline \multirow[t]{2}{*}{ CSV } & $0.014^{* * *}$ & $0.013^{* * *}$ & $0.013^{* * *}$ & $0.014^{* * *}$ \\
\hline & 0.000 & 0.000 & 0.000 & 0.000 \\
\hline \multirow[t]{2}{*}{ Stdv } & 0.086 & 0.108 & 0.110 & 0.090 \\
\hline & 0.178 & 0.122 & 0.115 & 0.159 \\
\hline \multirow[t]{2}{*}{ CEOP } & $0.067^{* *}$ & $0.066^{* *}$ & $0.062^{* *}$ & $0.064^{* *}$ \\
\hline & 0.013 & 0.024 & 0.039 & 0.019 \\
\hline Industry & included & included & included & included \\
\hline Wald test & 87.732 & 43.900 & 41.224 & 89.176 \\
\hline Prob (Wald test) & 0.000 & 0.000 & 0.000 & 0.000 \\
\hline System-Hausman & 0.098 & 0.328 & 0.223 & 0.007 \\
\hline Chi $^{2}(10 \%)$ & $6.251(3)$ & $6.251(3)$ & $6.251(3)$ & $6.251(3)$ \\
\hline
\end{tabular}


Panel B: Dependent Variable $=$ Tobin's $Q$

\begin{tabular}{|c|c|c|c|c|}
\hline & 1 & 2 & 3 & 4 \\
\hline \multirow[t]{2}{*}{$C$} & 1.017 & 0.988 & 1.078 & 0.887 \\
\hline & 0.142 & 0.163 & 0.131 & 0.197 \\
\hline \multirow[t]{2}{*}{ Rents } & 0.066 & & & 0.082 \\
\hline & 0.502 & & & 0.405 \\
\hline \multirow[t]{2}{*}{ Herf } & & 0.409 & & $0.460^{*}$ \\
\hline & & 0.140 & & 0.099 \\
\hline \multirow[t]{2}{*}{$\operatorname{Reg}$} & & & 0.074 & 0.072 \\
\hline & & & 0.575 & 0.576 \\
\hline \multirow[t]{2}{*}{ Sratio } & 0.521 & 0.388 & 0.612 & 0.480 \\
\hline & 0.578 & 0.686 & 0.536 & 0.608 \\
\hline \multirow[t]{2}{*}{ Stocksod } & $0.518^{* *}$ & 0.436 * & $0.485^{* *}$ & 0.427 * \\
\hline & 0.032 & 0.074 & 0.048 & 0.082 \\
\hline \multirow[t]{2}{*}{ Blocko } & -0.209 & -0.222 & -0.187 & -0.227 \\
\hline & 0.388 & 0.368 & 0.455 & 0.344 \\
\hline \multirow[t]{2}{*}{ Leverage } & 0.397 & 0.386 & 0.396 & 0.410 \\
\hline & 0.206 & 0.214 & 0.208 & 0.187 \\
\hline \multirow[t]{2}{*}{ Outsider } & -0.250 & -0.221 & -0.269 & -0.209 \\
\hline & 0.540 & 0.587 & 0.511 & 0.606 \\
\hline \multirow[t]{2}{*}{ Lnassets } & -0.001 & -0.009 & -0.012 & -0.011 \\
\hline & 0.990 & 0.843 & 0.803 & 0.803 \\
\hline \multirow[t]{2}{*}{$R O A$} & $2.002^{* * *}$ & $2.278^{* * *}$ & $2.164^{* * *}$ & $2.182^{* * *}$ \\
\hline & 0.000 & 0.000 & 0.000 & 0.000 \\
\hline \multirow[t]{2}{*}{ Pgrowth } & $0.357^{* * *}$ & $0.357^{* * *}$ & $0.346^{* * *}$ & $0.378^{* * *}$ \\
\hline & 0.003 & 0.002 & 0.003 & 0.002 \\
\hline \multirow[t]{2}{*}{ Beta } & $0.288^{* *}$ & $0.330^{* * *}$ & $0.324^{* * *}$ & $0.293^{* *}$ \\
\hline & 0.013 & 0.004 & 0.005 & 0.011 \\
\hline Industry & included & included & included & included \\
\hline Wald test & 41.319 & 52.406 & 52.304 & 44.936 \\
\hline Prob (Wald test) & 0.000 & 0.000 & 0.000 & 0.000 \\
\hline System-Hausman & 0.050 & 0.077 & 0.047 & 0.004 \\
\hline $\mathrm{Chi}^{2}(10 \%)$ & $6.251(3)$ & $6.251(3)$ & $6.251(3)$ & $6.251(3)$ \\
\hline
\end{tabular}

Results from estimating equations 4.1 (Panel A) and 4.2 (Panel B) simultaneously by 3 SLS. The sample size is 156 . A Wald test is performed for the simultaneous significance of all coefficients (except the constant and industry dummies). The numbers in parentheses are probability values for twosided tests. To test for the correctness of the specification of the system of two simultaneous equations, a Hausman specification test is applied. The test statistic is distributed Chi-squared and we report the respective $10 \%$ critical values. $* * * / * * / *$ denotes statistical significance at the $1 \% / 5 \% / 10 \%$ level. 
Table 8: Robustness tests - OLS regressions of Sratio on different measures of product market competition

\begin{tabular}{|c|c|c|c|c|c|c|c|}
\hline & \multicolumn{7}{|c|}{ Dependent Variable $=$ Sratio } \\
\hline & (1) & (2) & (3) & (4) & (5) & (6) & (7) \\
\hline \multirow[t]{2}{*}{$C$} & -0.070 & -0.080 & -0.074 & -0.047 & -0.080 & -0.067 & -0.024 \\
\hline & 0.635 & 0.380 & 0.617 & 0.762 & 0.586 & 0.653 & 0.884 \\
\hline \multirow[t]{2}{*}{ Rents } & -0.068 & & & & -0.068 & -0.066 & -0.068 \\
\hline & 0.106 & & & & 0.109 & 0.106 & 0.107 \\
\hline \multirow[t]{2}{*}{ Rents_02 } & & $-0.059^{* * *}$ & & & & & \\
\hline & & 0.000 & & & & & \\
\hline \multirow[t]{2}{*}{ Rents8 } & & & -0.051 & & & & \\
\hline & & & 0.143 & & & & \\
\hline \multirow[t]{2}{*}{ RentsL1 } & & & & -0.053 & & & \\
\hline & & & & 0.152 & & & \\
\hline \multirow[t]{2}{*}{ Herf } & -0.050 & -0.059 & -0.044 & -0.041 & & & -0.051 \\
\hline & 0.255 & 0.129 & 0.324 & 0.357 & & & 0.244 \\
\hline \multirow[t]{2}{*}{ Herf_02 } & & & & & -0.038 & & \\
\hline & & & & & 0.372 & & \\
\hline \multirow[t]{2}{*}{ Herf_MaSe } & & & & & & -0.111 & \\
\hline & & & & & & 0.159 & \\
\hline \multirow[t]{2}{*}{ Reg } & -0.008 & -0.007 & -0.008 & -0.007 & -0.007 & -0.008 & \\
\hline & 0.689 & 0.726 & 0.694 & 0.735 & 0.739 & 0.708 & \\
\hline \multirow[t]{2}{*}{ Reg_General } & & & & & & & -0.004 \\
\hline & & & & & & & 0.364 \\
\hline \multirow[t]{2}{*}{$Q$} & 0.008 & 0.006 & 0.007 & 0.007 & 0.007 & 0.006 & 0.008 \\
\hline & 0.504 & 0.523 & 0.547 & 0.526 & 0.526 & 0.584 & 0.485 \\
\hline \multirow[t]{2}{*}{ Stocksod } & 0.018 & 0.007 & 0.018 & 0.017 & 0.016 & 0.023 & 0.021 \\
\hline & 0.541 & 0.792 & 0.543 & 0.555 & 0.578 & 0.494 & 0.487 \\
\hline \multirow[t]{2}{*}{ Blocko } & $-0.085^{* *}$ & $-0.084^{\star *}$ & $-0.086^{* *}$ & $-0.085^{* *}$ & $-0.086^{* *}$ & $-0.093^{* *}$ & $-0.090^{* *}$ \\
\hline & 0.037 & 0.048 & 0.036 & 0.036 & 0.038 & 0.026 & 0.029 \\
\hline \multirow[t]{2}{*}{ Leverage } & -0.033 & -0.011 & -0.034 & -0.037 & -0.034 & -0.021 & -0.029 \\
\hline & 0.542 & 0.801 & 0.546 & 0.520 & 0.530 & 0.707 & 0.586 \\
\hline \multirow[t]{2}{*}{ Outsider } & $0.121^{* *}$ & $0.123^{* *}$ & $0.118^{* *}$ & $0.117^{* *}$ & $0.123^{* *}$ & $0.141^{\text {** }}$ & $0.116^{* *}$ \\
\hline & 0.038 & 0.035 & 0.044 & 0.044 & 0.035 & 0.025 & 0.047 \\
\hline \multirow[t]{2}{*}{ Lnassets } & 0.003 & 0.005 & 0.003 & 0.001 & 0.003 & 0.002 & 0.003 \\
\hline & 0.784 & 0.570 & 0.802 & 0.913 & 0.774 & 0.807 & 0.769 \\
\hline \multirow[t]{2}{*}{ csv } & $0.014^{* *}$ & $0.013^{*}$ & $0.014^{* *}$ & $0.014^{* *}$ & $0.014^{* *}$ & $0.014^{* *}$ & $0.014^{* *}$ \\
\hline & 0.042 & 0.051 & 0.041 & 0.042 & 0.043 & 0.035 & 0.040 \\
\hline \multirow[t]{2}{*}{$S t d v$} & 0.086 & 0.062 & 0.101 & 0.083 & 0.085 & 0.075 & 0.086 \\
\hline & 0.216 & 0.368 & 0.157 & 0.240 & 0.221 & 0.284 & 0.215 \\
\hline \multirow[t]{2}{*}{ CEOP } & $0.067^{* *}$ & $0.075^{* \star}$ & $0.066^{* *}$ & $0.067^{* *}$ & $0.067^{* *}$ & $0.071^{* *}$ & $0.065^{* *}$ \\
\hline & 0.038 & 0.013 & 0.043 & 0.040 & 0.036 & 0.028 & 0.041 \\
\hline Industry & included & included & included & included & included & included & included \\
\hline Adjusted $R^{2}$ & 0.318 & 0.412 & 0.299 & 0.293 & 0.311 & 0.318 & 0.315 \\
\hline F-statistic & 3.026 & 4.067 & 2.505 & 2.561 & 2.537 & 2.614 & 2.529 \\
\hline Prob(F-stat) & 0.002 & 0.000 & 0.005 & 0.004 & 0.005 & 0.004 & 0.005 \\
\hline
\end{tabular}


This table reports estimates from OLS regressions of the percentage of share-based to cash compensation (Sratio) on alternative measures of product market competition (Rents, Rents_02, Rents8, RentsL1, Herf, Herf_02, Herf_MaSe, Reg, and Reg_General) and different combinations of three measures together (one measure of rents, one Herfindahl index, and one measure of the level of regulation) along with Tobin's $Q(Q)$, four corporate governance mechanisms (Stocksod, Blocko, Leverage, and Outsider), and four control variables (Lnassets, CSV, Stdv, and CEOP). The sample size is 156 . An $F$-test is performed for the simultaneous significance of all coefficients (except the constant and industry dummies). The numbers in parentheses are probability values for two-sided tests. $* * * / * * / *$ denotes statistical significance at the $1 \% / 5 \% / 10 \%$ level. 
Table 9: Robustness tests - OLS regressions of Tobin's $Q$ on different measures of product market competition

\begin{tabular}{|c|c|c|c|c|c|c|c|}
\hline & \multicolumn{7}{|c|}{ Dependent Variable $=$ Tobin's $Q$} \\
\hline & (1) & (2) & (3) & (4) & (5) & (6) & (7) \\
\hline \multirow[t]{2}{*}{$C$} & 0.856 & 0.899 & 0.842 & 0.810 & 0.918 & 0.961 & 0.639 \\
\hline & 0.166 & 0.149 & 0.175 & 0.194 & 0.140 & 0.123 & 0.336 \\
\hline \multirow[t]{2}{*}{ Rents } & 0.072 & & & & 0.067 & 0.050 & 0.074 \\
\hline & 0.472 & & & & 0.509 & 0.650 & 0.458 \\
\hline \multirow[t]{2}{*}{ Rents_02 } & & -0.009 & & & & & \\
\hline & & 0.875 & & & & & \\
\hline \multirow[t]{2}{*}{ Rents8 } & & & 0.061 & & & & \\
\hline & & & 0.409 & & & & \\
\hline \multirow[t]{2}{*}{ RentsL1 } & & & & 0.079 & & & \\
\hline & & & & 0.266 & & & \\
\hline \multirow[t]{2}{*}{ Herf } & 0.457 & 0.414 & 0.458 & 0.465 & & & 0.458 \\
\hline & 0.108 & 0.150 & 0.106 & 0.100 & & & 0.102 \\
\hline \multirow[t]{2}{*}{ Herf_02 } & & & & & 0.345 & & \\
\hline & & & & & 0.219 & & \\
\hline \multirow[t]{2}{*}{ Herf_MaSe } & & & & & & -0.230 & \\
\hline & & & & & & 0.476 & \\
\hline \multirow[t]{2}{*}{ Reg } & 0.068 & 0.069 & 0.068 & 0.066 & 0.056 & 0.059 & \\
\hline & 0.525 & 0.516 & 0.524 & 0.535 & 0.613 & 0.603 & \\
\hline \multirow[t]{2}{*}{ Reg_General } & & & & & & & 0.020 \\
\hline & & & & & & & 0.336 \\
\hline \multirow[t]{2}{*}{ Sratio } & 0.323 & 0.172 & 0.322 & 0.346 & 0.314 & 0.293 & 0.330 \\
\hline & 0.283 & 0.543 & 0.277 & 0.247 & 0.298 & 0.347 & 0.277 \\
\hline \multirow[t]{2}{*}{ Stocksod } & 0.429 & 0.417 & 0.430 & 0.433 & $0.444^{*}$ & $0.529^{*}$ & 0.420 \\
\hline & 0.107 & 0.115 & 0.105 & 0.103 & 0.095 & 0.054 & 0.118 \\
\hline \multirow[t]{2}{*}{ Blocko } & -0.244 & -0.245 & -0.242 & -0.245 & -0.242 & -0.243 & -0.220 \\
\hline & 0.206 & 0.204 & 0.209 & 0.204 & 0.210 & 0.211 & 0.256 \\
\hline \multirow[t]{2}{*}{ Leverage } & 0.402 & 0.390 & 0.403 & 0.415 & 0.406 & 0.411 & 0.382 \\
\hline & 0.192 & 0.216 & 0.190 & 0.177 & 0.190 & 0.192 & 0.209 \\
\hline \multirow[t]{2}{*}{ Outsider } & -0.208 & -0.227 & -0.203 & -0.202 & -0.225 & -0.231 & -0.190 \\
\hline & 0.632 & 0.598 & 0.639 & 0.642 & 0.604 & 0.602 & 0.661 \\
\hline \multirow[t]{2}{*}{ Lnassets } & -0.007 & -0.007 & -0.006 & -0.005 & -0.006 & 0.003 & -0.006 \\
\hline & 0.895 & 0.888 & 0.908 & 0.929 & 0.914 & 0.955 & 0.906 \\
\hline \multirow[t]{2}{*}{$R O A$} & $2.170^{* *}$ & $2.316^{* *}$ & $2.180^{* *}$ & $2.158^{* *}$ & $2.145^{* *}$ & $2.007^{* *}$ & $2.146^{* *}$ \\
\hline & 0.026 & 0.017 & 0.023 & 0.024 & 0.029 & 0.036 & 0.026 \\
\hline \multirow[t]{2}{*}{ Pgrowth } & 0.376 & 0.356 & 0.377 & $0.379^{*}$ & 0.369 & 0.354 & $0.382^{*}$ \\
\hline & 0.101 & 0.117 & 0.101 & 0.097 & 0.110 & 0.137 & 0.094 \\
\hline \multirow[t]{2}{*}{ Beta } & $0.292^{* *}$ & $0.320^{* *}$ & $0.288^{*}$ & $0.291^{\text {** }}$ & $0.294^{* *}$ & $0.284^{*}$ & $0.286^{*}$ \\
\hline & 0.050 & 0.030 & 0.056 & 0.046 & 0.049 & 0.053 & 0.054 \\
\hline Industry & included & included & included & included & included & included & included \\
\hline Adjusted $R^{2}$ & 0.503 & 0.500 & 0.503 & 0.505 & 0.499 & 0.495 & 0.504 \\
\hline F-statistic & 2.483 & 2.313 & 2.509 & 2.609 & 2.451 & 2.384 & 2.594 \\
\hline Prob(F-stat) & 0.006 & 0.010 & 0.005 & 0.004 & 0.006 & 0.008 & 0.004 \\
\hline
\end{tabular}


This table reports estimates from OLS regressions of Tobin's $\mathrm{Q}(Q)$ on alternative measures of product market competition (Rents, Rents_02, Rents8, RentsL1, Herf, Herf_02, Herf_MaSe, Reg, and Reg_General) and different combinations of three measures together (one measure of rents, one Herfindahl index, and one measure of the level of regulation) along with the percentage of share-based to cash compensation (Sratio), four corporate governance mechanisms (Stocksod, Blocko, Leverage, and Outsider), and four control variables (Lnassets, ROA, Pgrowth, and Beta). The sample size is 156. An $F$-test is performed for the simultaneous significance of all coefficients (except the constant and industry dummies). The numbers in parentheses are probability values for two-sided tests. $* * * / * * * *$ denotes statistical significance at the $1 \% / 5 \% / 10 \%$ level. 